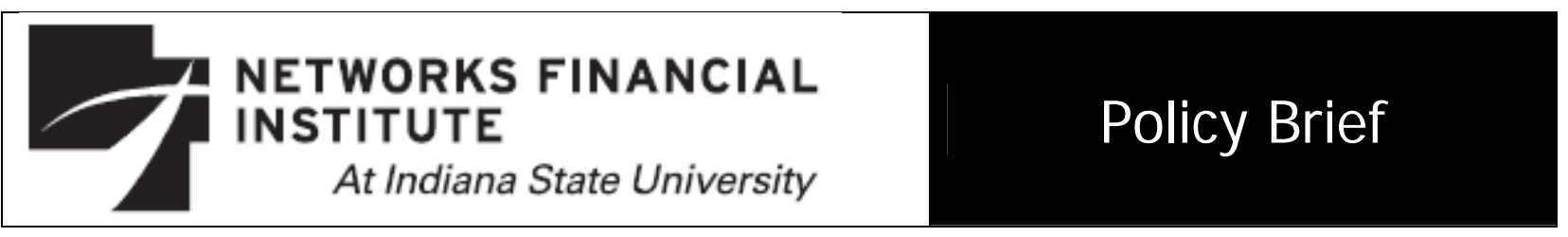

2013-PB-02

March 9, 2013

\title{
Systemic Risk and Regulation of the U.S. Insurance I ndustry
}

\section{J. David Cummins and Mary A. Weiss}

Abstract: This paper analyzes the characteristics of U.S. insurers for purposes of determining whether they are systemically risky. More specifically, primary factors (size, interconnectedness, and lack of substitutability) and contributing factors (leverage, liquidity risk and maturity mismatch, complexity and government regulation) associated with systemic risk are assessed for the insurance sector. A distinction is made between the core activities of insurers (e.g., underwriting, reserving, claims settlement, etc.) and non-core activities (such as providing financial guarantees). Statistical analysis of insurer characteristics and their relationship with a well-known systemic risk measure, systemic expected shortfall, is provided. Consistent with other research, the core activities of property-casualty insurers are found not to be systemically risky. However, we do find evidence that some core activities of life insurers, particularly separate accounts and group annuities, may be associated with systemic risk. The non-core activities of both property-casualty and life insurers can contribute to systemic risk. However, research findings indicate that generally insurers are victims rather than propagators of systemic risk events. The study also finds that insurers may be susceptible to intra-sector crises such as reinsurance crises arising from counterparty credit risk. New and proposed state and federal regulation are reviewed in light of the potential for systemic risk for this sector.

About the Authors: Dr. J. David Cummins is the Joseph E. Boettner Professor of Risk Management, Insurance and Financial Institutions. He also serves as the Director of the Advanta Center for Financial Institutions, and as a member of the Research Roundtable. Mary A. Weiss, Ph.D. is Deaver Professor of Risk, Insurance, and Healthcare Management at the Fox School of Business and Management of Temple University and President of the prestigious Risk Theory Society.

Keywords: Systemic risk, Insurance regulation, Financial Stability Oversight Council

\section{JEL classification: G20, G22, G90}

The views expressed are those of the individual authors and do not necessarily reflect official positions of Networks Financial Institute. Please address questions regarding content to J. David Cummins at cummins@temple.edu or Mary A. Weiss at mweiss@temple.edu The address for both is Department of Risk, Insurance, and Healthcare Management, Temple University, Alter Hall, 006-00 1801 Liacouras Walk, Philadelphia, PA 19122 Any errors or omissions are the responsibility of the authors.

NFI working papers and other publications are available on NFI's website (www. networksfinancialinstitute.org). Click "Research" and then "Publications/Papers." 


\section{Introduction}

Systemic risk can be defined as the risk that an event will trigger a loss of economic value or confidence in a substantial segment of the financial system that is serious enough to have significant adverse effects on the real economy with a high probability. ${ }^{1}$ Embedded in this definition of systemic risk are two important criteria: (1) economic shocks become systemic because of the spillover effects whereby there is a contagious loss of value or confidence that spreads throughout the financial system. Thus, the failure of one financial institution, even a very large one, which does not spread to other institutions, is not a systemic event. (2) Systemic financial events are sufficiently serious to have significant adverse effects on real economic activity. The financial crisis of 2007-2009 is a clear example of a systemic event which began in the housing market and spread to other parts of the financial system, resulting in significant declines in stock prices and real GDP.

In response to the most recent systemic crisis, the Dodd-Frank Wall Street Reform and Consumer Protection Act of 2010 was passed into law. This law required the formation of an important new regulatory agency with potential authority over insurance holding companies, the Financial Stability Oversight Council (FSOC). One of the primary purposes of FSOC is to identify risks to the financial stability of the U.S. that could arise from the activities of large, interconnected bank holding companies or nonbank financial companies (emphasis added) (FSOC, 2012). Therefore, one of the activities of FSOC is the identification of nonbank financial companies that are Systemically Important Financial Institutions (SIFIs). Insurers are examples of nonbank financial companies that could potentially be designated as SIFIs. Organizations designated as SIFIs would come under the supervision of the Federal Reserve Board and be subject to enhanced capital requirements, liquidity requirements, short-term debt limits and public disclosures, as mandated under the Dodd-Frank Law.

The purpose of this paper is threefold: First, the activities of U.S. insurers are evaluated to determine whether U.S. insurers are systemically risky. An important distinction in this analysis is made between the core activities of insurers, such as insurance underwriting, reserving, claims settlement, and reinsurance, and the non-core or banking activities engaged in by some insurers (such as AIG). Non-core activities include provision of financial guarantees, asset lending, issuing credit default swaps (CDS), investing in complex structured securities, and excessive reliance on short-term sources of financing. Second a statistical analysis is conducted which consists of a correlation analysis of insurer characteristics (such as the notional value of derivatives not used for hedging) and a well-known systemic risk measure, SRISK. (See Acharya, Engle, and Richardson, 2012 for a discussion of this measure.) Robust ordinary-leastsquares (OLS) analysis is performed also on a small set of insurers to determine firm characteristics associated with systemic risk. Finally, regulatory responses to the financial crisis as they relate to insurers are discussed. The latter includes criteria that FSOC uses to designate nonbank financial companies as SIFIs.

Although prior studies have concluded that the insurance industry as a whole is not systemically risky, this research still contributes to the literature for a number of reasons. First, recent micro studies of insurers (i.e., studies of individual insurers) have suggested that linkages

\footnotetext{
${ }^{1}$ This definition of systemic risk is analogous to the definition proposed in Group of Ten (2001, p. 126). Similar definitions have been proposed by other organizations. See, for example, Financial Stability Board (2009).
} 
between banks, insurers, hedge funds, and other financial firms may be more significant than prior research indicates (Billio et al., 2011 and Acharya, et al., 2010). A second reason for conducting further analysis of the U.S. insurance industry is that most prior studies have been oriented towards the global insurance and reinsurance industries rather than conducting an indepth analysis of the U.S. industry (e.g., Swiss Re, 2003; Group of 30, 2006; Bell and Keller, 2009; Geneva Association, 2010; and Baluch, Mutenga, and Parsons, 2011). A third rationale is that several of the prior studies on the topic have been published or sponsored by the insurance industry (e.g., Swiss Re, 2003; Bell and Keller, 2009; and Geneva Association, 2010). Therefore it is important to provide an independent, third-party analysis. The fourth reason to conduct additional analysis of systemic risk in the U.S. insurance industry is that the reinsurance counterparty risk of U.S. licensed insurers has rarely been investigated systematically in any detail. $^{2}$

This paper contributes to the literature in other ways. A systemic risk measure developed by Acharya et al., (2010) is analyzed to determine which aspects of an insurer are associated with systemic risk. This analysis relies on data obtained from the 10-K reports filed with the SEC by each individual insurer as well as data available from public data bases (the SNL Financial database, Compustat, and the National Association of Insurance Commissioners (NAIC)). The sample period studied is 2001-2011, and the sample includes all major publicly traded life and property-casualty (P-C) insurance groups for which data are available.

The findings of this study provide a somewhat more nuanced view of systemic risk in the insurance industry than most prior research. By way of preview, we find that the core activities of P-C insurers do not contribute to systemic risk. However, we find evidence suggesting that some activities of life insurers, particularly group annuities and separate accounts, do contribute to systemic risk. However, in general, insurers are victims rather than propagators of systemic risk. As was demonstrated by the AIG debacle, the non-core activities of insurers do constitute a potential source of systemic risk, and interconnectedness among financial firms has grown significantly in recent years. Therefore on a world-wide scale, regulators need to significantly improve their capabilities in group supervision.

The remainder of this paper proceeds as follows. First, a short literature review on systemic risk and the insurance industry is conducted. Following this, primary and contributing factors to systemic risk are discussed. Then these criteria are evaluated with respect to the U.S. insurance industry. The next section analyzes the non-core activities of insurers in terms of their potential for causing systemic risk. In the succeeding section, data analysis based on insurers' systemic risk measures is conducted. Following this, potential forthcoming changes in insurance regulation to address systemic concerns are discussed, and the last section contains concluding comments.

\section{Literature Review}

There have been a few prior studies of systemic risk in the insurance industry. These can be broadly classified as industry-sponsored or academic. Both types of research are reviewed briefly below.

\footnotetext{
${ }^{2}$ The exception is a single paper on P-C insurance by Park and Xie (2012), which is briefly discussed below. Life insurance counterparty relationships have not previously been analyzed. Cummins and Weiss (2012) also look at reinsurance counterparty relationships.
} 


\section{Industry-Sponsored Research}

Some prior research has focused on whether reinsurance creates systemic risk for the insurance industry. Swiss Re (2003) investigates whether reinsurers pose a major risk for their clients, the financial system or the economy. The broad conclusion is that systemic risk does not exist in reinsurance, but the study concedes (presciently) that reinsurers are linked to the banking sector via credit derivatives, the same instruments that brought down AIG. A study by the Group of 30 (2006) also investigates the degree to which the reinsurance sector may pose systemic risk. The study presents the results of a "stress test" projecting the results of reinsurer failures equivalent to 20 percent of the global reinsurance market. The conclusions are that even failures of this magnitude would be unlikely to trigger widespread insolvencies among primary insurers and that the effects on the real economy would be minimal.

Bell and Keller (2009) investigate the systemic risk of the insurance industry, concluding that insurers engaged in insurance (core) activities are not systemically risky. As a consequence, they are not "Too Big To Fail” (TBTF) or "too interconnected to fail." However, they argue that insurers engaging in non-traditional activities such as credit derivatives can pose systemic risk, which can be controlled through more rigorous risk-based capital requirements. Similar to Bell and Keller (2009), the Geneva Association (2010) concludes that insurers did not play a major role in the financial crisis aside from monolines and insurers engaging in non-traditional activities such as credit default swaps. Two non-core activities are identified as potential sources of systemic risk: (1) derivatives trading on non-insurance balance sheets and (2) mismanagement of short term funding from commercial paper or securities lending.

\section{Academic Studies}

Grace (2010) conducts a series of tests on insurer stock prices to help determine "whether insurers contribute to systemic risk or whether they are potential victims of systemic risk." The findings suggest that AIG was systemically important but that generally the insurance industry is not a significant source of systemic risk.

Acharya et al., (2010) uses stock price data and finds that several insurers ranked highly based on an econometric measure of systemic risk when compared to systemically important banks. Billio et al., also use stock price data and conclude that "a liquidity shock to one [financial] sector propagates to other sectors eventually culminating in losses, defaults, and a systemic event.” The study also finds that financial firms have become more highly interrelated and less liquid during the past decade. A more recent micro-level analysis by Chen et al., (2012) constructs a systemic risk measure to examine the inter-connectedness between banks and insurers. The results indicate that the impact of banks on insurers is stronger and of longer duration than the impact of insurers on banks. Stress tests confirmed that banks create economically significant systemic risk for insurers but not vice versa.

Baluch, Mutenga, and Parsons (2011) investigate the role of the insurance industry in the financial crisis with an emphasis on European markets. Their analysis reveals significant correlation between the banking and insurance sectors and finds that the correlation increased during the crisis period. They conclude that systemic risk is lower in insurance than in banking but has grown in recent years due to increasing linkages between banks and insurers and growing exposure to non-traditional insurance activities. 
Cummins and Weiss (2012) perform an analysis of the overall U.S. insurance industry with respect to systemic risk and conclude that the core activities of U.S. insurers do not pose systemic risk. To provide further information on the non-core activities of insurance firms, an analysis was conducted on systemic and non-systemic risk samples. The results indicated that the systemic firms had more business segments on average than non-systemic insurers and the difference was statistically significant. Based on their tests, systemic firms on average had higher derivatives holdings both for hedging and for non-hedging purposes than the nonsystemic firms. ${ }^{3}$ Also, systemic insurers had larger amounts of multi-class commercial mortgage- backed securities (MBS) and total private asset-backed securities (ABS).

Thus, the hallmarks of previous research are that, taken as a whole, insurers are not systemically risky, as long as they are engaged in insurance core activities (insurance underwriting, reserving, claims settlement, and reinsurance). Studies of individual insurers, based primarily on stock prices and/or credit default swap spreads suggest that some individual insurers rank highly with respect to systemic risk measures. Of course, stock prices and credit default swap spreads reflect both core and non-core activities of insurers. This leaves open the question as to whether it is non-core activities that are causing high systemic risk measures in individual insurer studies.

\section{Primary and Contributing Factors for Systemic Risk}

This analysis distinguishes between primary indicators of systemic risk and factors contributing to vulnerability to systemic risk (Financial Stability Board, 2009). The primary indicators are criteria that are useful in identifying systemically risky markets and institutions, whereas the contributing factors are criteria that can be used to gauge financial vulnerabilities and the capacity of the institutional framework to deal with financial failures. That is, it is possible for an institution to be systemically important but not relatively vulnerable. This discussion provides conceptual background for the analysis of the systemic importance and vulnerability of the U.S. insurance industry.

It should be emphasized that instigating or causing a systemic crisis is not the same as being susceptible to a crisis. To instigate a systemic crisis, the shock or event must first emanate from the insurance sector due to specific activities conducted by insurers and then spread to other financial sectors and the real economy. Thus evidence that the insurance industry did poorly in the financial crisis does not necessarily mean it is systemically important in the sense of being the cause of systemic events. Chen et al. (2012) provide empirical evidence that most insurers tend to be victims rather than propagators of systemic events.

\section{Primary Indicators for Systemic Risk}

The three primary indicators of systemic risk are: (1) size of exposures (volume of transactions or assets managed); (2) interconnectedness; and (3) lack of substitutability. ${ }^{4}$ These

\footnotetext{
${ }^{3}$ Prudential was omitted from the analysis to obtain this result. See Cummins and Weiss (2012).

${ }^{4}$ Our primary indicators are based on those identified in Financial Stability Board (2009). The International Association of Insurance Supervisors (IAIS) (2009) proposes a fourth factor, timing, based on the argument that systemic insurance risk propagates over a longer time horizon than systemic risk in banking. The International Monetary Fund (IMF) considers size, interconnectedness, leverage, and (risky) funding structure in assessing the
} 
factors have been identified as having a high potential for generating systemic risk, i.e., they are not necessarily associated with systemic risk in every instance. This is especially true of size. For example, a large firm may not pose a systemic problem if it is not interconnected or if its products do not lack substitutes. ${ }^{5}$ The remainder of this section discusses these indicators.

The size of an institution is frequently measured by its assets or equity, in absolute terms or relative to GDP. However, the financial crisis of 2007-2010 demonstrated that conventional balance sheet measures of size may not capture an institution's systemic importance. For example, the now defunct Financial Products division of AIG wrote hundreds of billions of dollars of credit default swap coverage with relatively little capitalization, suggesting that notional value of derivatives exposure and potential loss to a firm's counterparties should also be considered when analyzing size. Gauges of size that may be more relevant than conventional measures are the value of off-balance-sheet (OBS) exposures of the institution and the volume of transactions it processes. Systemic risk associated with size can also arise from clusters of smaller institutions with similar business models and highly correlated assets or liabilities, such that the cluster has the systemic impact of a much larger firm.

Interconnectedness, the second primary risk factor, refers to the degree of correlation and the potential for contagion among financial institutions (i.e., the extent to which financial distress at one or a few institutions increases the probability of financial distress at other institutions because of the network of financial claims and other inter-relationships). This network or "chain" effect operates on both sides of the balance sheet as well as through derivatives transactions, OBS commitments, and other types of relationships. The propagation of systemic problems through interconnectedness or contagion usually requires exposure to a common shock or precipitating event such as a depression in agriculture or real estate or an increase in oil prices (Kaufman and Scott, 2003). In the crisis of 2007-2010, the common shock was the bursting of the housing price bubble. The housing shock triggered losses on MBS and generated a "run" on the shadow banking system involving inter-bank lending, commercial paper, and the market for short-term repurchase agreements (“repos”). ${ }^{6}$

The third primary indicator of systemic risk is lack of substitutability, where substitutability is defined as the extent to which other institutions or segments of the financial system can provide the same services that were provided by the failed institution or institutions. In order for lack of substitutability to pose a systemic problem, the services in question must be of critical importance to the functioning of other institutions or the financial system, i.e., other institutions must rely on the services to function effectively (e.g., payment and settlement systems). So, in analyzing the systemic risk of the insurance industry, it is important to

systemic importance of institutions (IMF, 2009). Our taxonomy also considers leverage and funding structures but classifies these as contributing factors rather than primary indicators.

${ }^{5}$ As pointed out in Financial Stability Board (2009, p. 9), "While size can be important in itself, it is much more significant when there are connections to other institutions. The relevance of size will also depend on the particular business model and group structure, and size may be of greater systemic concern when institutions are complex (see below) ... for example, well-capitalized large institutions with simpler business models and exposures can be a source of stability in times of stress.”

${ }^{6}$ The shadow banking system consists of financial intermediaries that provide banking-like services without access to central bank liquidity or explicit public sector credit guarantees. Shadow banks are less stringently regulated than commercial banks. Shadow banks include finance companies, structured investment vehicles, hedge funds, assetbacked commercial paper conduits, money market mutual funds, securities lenders, and government-sponsored enterprises. For further information see Pozsar et al. (2010). 
determine not only whether there are adequate substitutes for insurance, but also whether insurance is actually critical for the functioning of economic markets to the same degree as payments, settlements, liquidity, and short-term credit.

One quantitative indicator that captures aspects of substitutability is market concentration, measured by market shares of the leading firms or the Herfindahl index. Ease of market entry is also important, including technological, informational, and regulatory barriers that prevent new entrants from replacing the services of financially troubled firms. Qualitative evaluations of the degree to which key financial sector participants depend upon specified services also are important in determining substitutability.

\section{Contributing Factors to Systemic Risk}

Although the number of factors contributing to systemic risk is potentially larger, four factors are emphasized in this discussion: (1) leverage, (2) liquidity risks and maturity mismatches, (3) complexity, and (4) government policy and regulation. These measures can be considered indicators of the vulnerability of systemically important institutions to financial distress resulting from idiosyncratic or system-wide shocks.

Leverage is an indicator of vulnerability to financial shocks and also of interconnectedness, i.e., the likelihood that an institution will propagate distress in the financial system by magnifying financial shocks. Highly-levered firms are vulnerable to loss spirals, because declines in asset values erode the institution's net worth much more rapidly than their gross worth (total assets) (Brunnermeier, 2009). For example, a firm with a 10-to-1 assets-toequity ratio that loses half of its equity due to a loss of asset value would have to sell nearly half of its assets to restore its leverage ratio after the shock. ${ }^{7}$ But selling assets after a price decline exacerbates the firm's losses. If many institutions are affected at the same time, the quest to sell assets puts additional downward pressure on prices, generating the loss spiral. Leverage can be measured in various ways, including the ratio of assets-to-equity or debt-to-equity. Ideally, a measure of leverage would include both on and off-balance-sheet positions. Leverage can also be created through options, through buying securities on margin, or through some financial instruments.

Liquidity risk and asset-liability maturity mismatches also increase financial firm vulnerability to idiosyncratic and systemic shocks. Liquidity can be broken down into two categories - market liquidity (the tradability of an asset) and funding liquidity (the ability of the trader to fund its trades) (Brunnermeier and Pederson, 2009). Market liquidity risk arises if an institution holds large amounts of illiquid assets. Such positions are vulnerable if the institution encounters difficulties obtaining financing (funding liquidity risk), triggering the need to liquidate all or part of its asset holdings. Liquidity risk is exacerbated by the extent of an institution's asset-liability mismatch. For example in the recent crisis, the use of short-term financing vehicles exposed the shadow banks to funding liquidity risk, i.e., the risk that investors will stop investing in commercial paper and other short-term investments, requiring the bank to liquidate positions in longer-term assets under unfavorable market conditions.

\footnotetext{
${ }^{7}$ With a 10-to-1 assets-to-equity ratio, a 5 percent decline in asset values would wipe out half of equity. If liabilities remained unchanged, the firm would need to sell about 47.4 percent of assets and use the proceeds to pay off liabilities in order to restore its assets-to-equity ratio to the pre-shock level.
} 
Related to liquidity is optionability or marginability of a firm's assets, liabilities or derivatives positions. Optionability refers to the ease with which an institution's counterparties can reverse their positions and/or require the institution to post additional margin or collateral to such positions. Optionability is a function of the contractual relationships between counterparties. Some types of financial contracts (e.g., bank demand deposits) are optionable, while other types are not (e.g., P-C insurance policies). In the former case, depositors can demand their deposits at any time, whereas in the latter, the policyholder must have a legitimate claim, which is subject to an orderly settlement process.

The complexity of a financial institution and/or its asset and liability positions also can exacerbate vulnerability to financial shocks. Complexity has several important dimensions: (1) Complexity of the organization, including its group structure and subsidiaries. For example, diversified financial services firms offering banking, insurance and investment products are more complex than single-industry firms. (2) Geographical complexity. That is, firms operating internationally are more complex than those focusing only on one or a few national markets. Multi-national firms are exposed to a wider variety of local and regional risk factors as well as multi-jurisdiction regulatory risk. (3) Product complexity. Firms that are highly exposed to new and complex financial products are more vulnerable to shocks. Such products expose firms to risks that may not be completely understood. Complexity played a major role in the AIG debacle during the financial crisis. AIG was a large and complex organization, and its Financial Products division was heavily involved in complex CDS operations without fully understanding the risks. The complexity and opacity of the organization, its geographical diversity and its complex products impeded monitoring by both management and regulators, contributing to the crisis.

Government policy and regulation also can contribute to financial system fragility. For example, deposit insurance and insurance guaranty fund protection reduce the probability of bank or insurance runs but also create moral hazard for banks and insurers, increasing the risk of financial distress (Acharya et al., 2009). Regulation can also create other types of adverse incentives. AIG sold large quantities of CDS to European banks that were using the contracts to reduce their required capital through regulatory arbitrage. The complexity and opacity of AIG Financial Products contributed to creating a regulatory blind-spot that permitted the subsidiary to operate with excessive leverage. Further, regulation intended to enhance the solvency of the regulated financial institution actually can exacerbate a crisis. For example, an increase in capital requirements can occur in times of financial distress, resulting in asset sales or further restrictions on the ability to create credit. Thus, capital requirements can be pro-cyclical.

\section{Primary and Contributing Factors for Systemic Risk for U.S. Insurers: Core Activities}

\section{Size and Core Activities}

The first primary indicator of systemic risk is size. In terms of balance sheet aggregates, insurers are smaller than banks. U.S. insurers (including life and P-C) had \$7.1 trillion of assets in 2011 including separate accounts and \$5.3 trillion excluding separate accounts, compared to $\$ 12.6$ trillion in the banking sector. The largest U.S. insurance group, MetLife, had \$612.8 billion in assets in 2011, compared with more than $\$ 2.3$ trillion for the top bank, J.P. Morgan 
Chase. ${ }^{8}$ Insurance contributes about 3.0 percent to total GDP, and insurers hold 7.8 percent of U.S. credit market debt outstanding. To see more details of the role of insurers in the securities markets refer to Table 1, which shows the percentage share of banks and insurers in the markets for various types of assets. P-C insurers are not a very important source of funds in any of the asset categories shown, with the exception of municipal securities, where they account for 8.8 percent of outstanding asset holdings in 2011. Life insurers are more important, accounting for 18.4 percent of corporate and foreign bonds, 11.8 percent of commercial mortgages, and 6.4 percent of equities in 2011.

However, because insurer insolvency resolutions are orderly and take place over lengthy periods of time, the amount of assets that would be liquidated in even the largest insurer insolvency would be small relative to securities markets. The failure rates of U.S. insurers and commercial banks are shown in Figure 1. This figure confirms that life insurers and banks were much more strongly affected by the financial crisis than were P-C insurers. ${ }^{9}$ The bank failure rate increased by a factor of 10, from 0.2 percent in 2007 to 1.9 percent in 2009-2010 and recovered somewhat to 1.6 percent in 2011. The life insurer failure rate rose by a factor of five from 0.19 percent in 2006 to 0.94 percent in 2009 but declined to 0.14 percent by 2011. By contrast, the P-C failure rate in 2009-2010 was about the same as the failure rate in 2005-2006. During the crisis, the P-C failure rate remained significantly below earlier peaks in 1989 to 1993 and from 2000-2003, which were driven by catastrophic events such as Hurricane Andrew and the 2001 terrorist attacks. Thus historically, underwriting events have created more insolvency risk for P-C insurers than financial crises, whereas banks and life insurers are more susceptible to financial market shocks. The bivariate correlations of the failure rates for the three types of institutions are statistically significant, providing evidence of susceptibility to common shocks (see Figure 1). Failure rates of the two types of insurers are more highly correlated with each other than with bank failure rates.

Insurers that are seriously financially impaired are handled in one of two ways in the U.S. The insurer may be placed into receivership while the liabilities are "run-off."10 Note that loss payments under policies do not actually become due until some point in the future (often years) so the receiver operates the insurer to pay off (or run off) losses as they actually come due. This spreads the effect of the insolvency over several future years. Alternatively, especially for life insurers, the business of the insolvent insurer may be sold to another insurer, with the policies continued under the new insurer. ${ }^{11}$ For a life insurer insolvency resolved by selling the insolvent insurer's business to another insurer, the guaranty fund (described below) assesses an amount sufficient to make the sale attractive to the acquirer. In P-C insurance, it is necessary to have a valid claim, which is processed through an orderly settlement process, in order to obtain payment from the insurer. Some claims on life insurers do represent withdrawable assets, and there is some risk that many policyholders would surrender their policies as an insurer becomes financially distressed, causing a liquidity problem. However, insolvent insurers typically have substantial assets on hand to cover liabilities when they fail because losses are prepaid through premiums. Thus liquidation of assets at distressed prices usually does not occur nor are

\footnotetext{
${ }^{8}$ The other three mega-banks are Bank of America, Citigroup, and Wells Fargo each of which had more than \$1 trillion of assets in 2012 (Standard \& Poor's, 2012). The bank data are for March 2012.

${ }^{9}$ The failure rate is defined as the number of failures divided by the total number of institutions.

${ }^{10}$ An insolvent insurer is defined as an insurer which is in receivership or liquidation.

${ }^{11}$ In other words, life guaranty funds often replace policyholders' coverage not policyholders' cash.
} 
immediate settlements to all policyholders made at the time of bankruptcy. ${ }^{12}$

In many countries, a safety net exists to provide protection for policyholders of insolvent insurers in the form of guaranty funds. Each state in the U.S. operates a life insurance guaranty fund and at least one P-C guaranty fund. The typical funding approach in the U.S. is postassessment $^{13}$ — solvent insurers are assessed each year to cover shortfalls in loss payments for insolvent insurers subject to annual maxima. There are restrictions on guaranty fund coverage, e.g., on maximum loss payable; and coverage generally does not apply to all lines of business. ${ }^{14}$

U.S. guaranty fund coverage and the state regulatory solvency resolution system in general apply to insurance companies that are U.S. licensed and regulated. Hence the creditors of AIG Financial Products were not covered by U.S. guaranty funds. If any of AIG's U.S. licensed insurance subsidiaries had become insolvent as the result of their asset lending operations, the policyholders of the insurers but not the asset lending counterparties would have been covered by guaranty funds.

The assessment system is designed to place minimal stress on solvent insurers while protecting the policyholders of insolvent insurers. Guaranty funds in the U.S. have the ability to borrow against future assessments if losses covered by the guaranty fund in any one year would place a financial strain on solvent insurers. U.S. guaranty funds have successfully paid claims of several large insolvent insurers, including Reliance, Executive Life, and Mutual Benefit Life. In 2010 the maximum annual assessment capacity of life insurers was $\$ 10.3$ billion, and the assessment capacity of P-C guaranty funds was $\$ 6.7$ billion. ${ }^{15}$ Insolvencies larger than the annual assessment capacity could be financed because insurer insolvencies tend to be resolved over several years and because the shortfall between liabilities and assets typically is not very large. ${ }^{16}$ Thus assessments would be likely to continue until all claims are paid (Gallanis, 2009).

Table 2 provides statistics regarding guaranty fund assessments for the period 1988 to 2010. Because of the orderly resolution of insurer insolvencies, guaranty funds assessments in both life and P-C insurance historically have been quite small. The total amounts of assessments from life-health and P-C guaranty funds from 1988 to 2010 were $\$ 6.3$ billion and $\$ 12.5$ billion, respectively; and the average annual assessments were \$276 million for life insurers and \$544 million for P-C insurers. Annual assessments never exceeded 0.35 percent of total premiums for either life or P-C insurers. Thus historically, the guaranty fund system has stood up very well; but the system has never been required to deal with a widespread solvency crisis in insurance markets.

\footnotetext{
${ }^{12}$ Policyholder claim/benefit payments are typically frozen for a period of time, except for death and financial need.

${ }^{13}$ New York is an exception. The rationale for ex post assessments is that, unlike the obligations of the FDIC, insurance payments under policies are spread over many years in the future as claims arise.

${ }^{14}$ In the U.S. small policyholders are typically protected by guaranty funds. Commercial insurance is covered also, but more than half of the states have a net worth restriction, such that if a company has net worth above some threshold (usually $\$ 25-50$ million) they are excluded from coverage. In addition, workers compensation insurance is always covered, while a few lines such as title insurance and mortgage guaranty insurance are not covered.

${ }^{15}$ Life guaranty fund capacity is from the National Organization of Life \& Health Insurance Guaranty Associations, http://www.nolhga.com/factsandfigures/main.cfm/location/assessmentdata. P-C guaranty fund capacity is from NCIGF (2011), http://www.ncigf.org/.

${ }^{16}$ For example, in a life insurer insolvency, the shortfall in assets relative to liabilities is typically in the five to 10 percent range and seldom is as high as 15 percent (Gallanis, 2009, p. 7).
} 
In summary, with respect to size, insolvency resolutions are orderly and take place over lengthy periods of time, hence the amount of assets that would be liquidated in even the largest insurer insolvency would be small relative to securities markets. Therefore, in terms of their core activities, insurers are not large enough to be systemically important, although the failure of a large insurer, such as a large subsidiary of MetLife, could cause significant dislocations in insurance markets and possibly strain the liquidity of insurance guaranty funds.

\section{Interconnectedness and Core Activities}

Insurance core activities do not seem to be systemically important in terms of the second primary indicator, interconnectedness. Unlike in many European countries, the cross-holdings of stocks and bonds between the U.S. insurance and U.S. banking industries are small, and neither industry provides a significant source of financing for the other. Thus, a commercial paper-like credit crunch arising from the U.S. insurance industry is highly unlikely.

That is, in 2010, bank bonds represented only 5.4 percent of the bond portfolio of P-C insurers, and bonds of other financial firms represented only 1.2 percent of P-C bonds. ${ }^{17}$ Banking and financial firm bonds represent 11.4 percent of equity for P-C insurers. Thus defaults by financial firms do not pose a serious threat to P-C insurers. Life insurers have eight percent of their bond portfolio invested in bank bonds and 1.7 percent invested in the bonds of other financial firms. Bank and finance bonds represent $62.1 \%$ of equity for life insurers. Hence, life insurers do face a potential threat from bond default by financial firms, although massive defaults would have to occur in order to pose an industry-wide threat to solvency. In 2008, less than one percent of stocks held by U.S. insurers were invested in bank stocks and a negligible proportion in stocks of securities firms.

Regarding the importance of insurers as sources of funds for other financial institutions, U.S. insurers held approximately 9.4 percent of banks' “other borrowed money" in 2008. However, borrowed money is not the primary source of financing to banks, amounting to less than 10 percent of liabilities. U.S. insurers held 14.1 percent of securities firms' outstanding corporate bond debt in 2008, but bonds represent only 11.2 percent of securities firms' financings (liabilities). U.S. insurers hold only negligible portions of securities firms' and banks' stock outstanding. Hence interconnectedness risk from security holdings in other types of financial firms does not seem to be a significant problem for U.S. insurers. ${ }^{18}$

Also with respect to interconnectedness, the bank failure rate has a bivariate correlation of 34 percent with the P-C insurer failure rate and 23 percent with life insurers, suggesting that banks and insurers are somewhat interconnected with respect to susceptibility to common economic and financial shocks. Chen et al. (2012) find banks create significant systemic risk for insurers but not vice versa, i.e., suggesting that insurers are victims rather than propagators of systemic risk.

To provide further information on interconnectedness in the U.S. insurance industry, the

\footnotetext{
${ }^{17}$ The data in this paragraph and the following paragraph are from NAIC (2011) and unpublished NAIC data.

${ }^{18}$ Cross-holdings between banks and insurers can be substantial in Europe, and bancassurance is more common there than in the U.S. Thus in Europe a systemic link can exist between insurers and banks such that a large event for an insurer can spread to an affiliated bank and vice-versa. For example, Allianz owned Dresdner Bank from 2001-2008. Multibillion write-downs by Dresdner Bank adversely affected Allianz's equity and balance sheet as well as some of its key capital ratios (Baluch, Mutenga, and Parsons, 2011).
} 
principal triggering events for life and P-C insurer insolvencies are shown in Table 3 for the period 1969 to 2011. Table 3 shows that life insurers have been vulnerable to interconnectedness with affiliates - affiliate problems are associated with 18.1 percent of life insurer failures. Life insurers are also susceptible to asset quality issues - investment problems trigger 15 percent of insolvencies. The primary triggers of life insurance insolvencies arise from bad management decisions such as under-pricing (29.1 percent of insolvencies), excessive growth (14.1 percent of insolvencies) and alleged fraud (8.8 percent of insolvencies). Likewise, for P-C insurers underpricing, excessive growth, and fraud together account for 62.5 percent of insolvencies. Interconnectedness with reinsurers and affiliates together are the triggering events for 11.5 percent of P-C insurer insolvencies. ${ }^{19}$ Unlike life insurers, P-C insurers are vulnerable to natural catastrophes, which account for 7.1 percent of failures. Therefore, except perhaps for life insurer affiliate problems, interconnectedness has not been a major cause of insurer insolvencies.

As a final comment on relationships with non-insurance corporations, life insurer participation in markets for products such as group annuities and separate accounts may create interconnectedness risk. In terms of these products, life insurers are often dealing with large corporate clients who control large blocks of assets, and such products are susceptible to withdrawals and other interruptions of cash flows during a crisis. Further research is needed to determine the relationship between various life insurance products and systemic risk.

Interconnection risk for core activities within the insurance industry is considerably higher than between insurance and banking, although risk confined within a specific sector is not systemic by definition. In particular, reinsurance is the primary source of interconnectedness within the insurance industry. Although past research indicates that reinsurance has not been an overriding cause of insolvencies in the past (see Table 3 and the literature review section of this paper), the reinsurance market has become increasingly concentrated over time, through mergers and acquisitions and organic growth (Cummins and Weiss, 2000; Cummins, 2007).

In addition, interlocking relationships permeate the industry, such that reinsurers retrocede (or resell) reinsurance to other reinsurers, who then retrocede business to still other reinsurers in a pattern reminiscent of the counterparty interrelationships that brought down the shadow banking system. ${ }^{20}$ Thus the reinsurance market is vulnerable to a retrocession spiral whereby the failure of major reinsurers triggers the failure of their reinsurance counterparties, who in turn default on their obligations to primary insurers, resulting in a crisis permeating the insurance industry on a worldwide scale. An example of a reinsurance spiral is the London Market Excess (LMX) spiral that unfolded in the late 1980s and early 1990s (Neyer, 1990). Baluch, Mutenga and Parsons (2011) argue that if Lloyds had failed, the lack of cover for the types of risks typically underwritten by Lloyds would have caused "significant economic disruption." Thus analysis of reinsurance counterparty relationships is important in understanding systemic risk in insurance.

Insurers conduct reinsurance transactions with both affiliates and non-affiliates. Although non-affiliate reinsurance is generally considered to pose more counterparty risk than

\footnotetext{
${ }^{19}$ Based on international data, Swiss Re (2003) also concludes that reinsurance failures historically have not been an important cause of insolvencies in the primary insurance industry.

${ }^{20}$ Some have likened the retrocession market to interbank lending and borrowing in the banking industry. As such it is sometimes thought to be a transmission mechanism for contagion and systemic risk within the reinsurance industry. But unlike MBS in the recent crisis, retroceders still retain part of the risk (to reduce adverse selection).
} 
affiliate reinsurance, the analysis of insurer insolvency history shows that affiliate problems also can pose an insolvency threat to insurers. Therefore this analysis considers reinsurance with both affiliates and non-affiliates. The analysis also focuses on primary insurer cessions into the reinsurance market rather than reinsurance assumed. ${ }^{21}$ Ceding reinsurance creates more counterparty risk than assuming reinsurance because the ceding insurer is dependent upon the reinsurer to pay claims. Additionally, the reinsurance counterparty usually holds the funds, unlike reinsurance assumed, where the assuming insurer usually holds the funds.

Several important financial statement variables measure an insurer's exposure to reinsurance counterparty risk. One measure that is important in both life and P-C insurance is reinsurance premiums ceded. Reinsurance receivables, which represent funds currently owed to the insurer under reinsurance transactions, are also an important measure of exposure. ${ }^{22}$ One of the benefits of buying reinsurance is that the buyer is generally permitted to reduce its reserve liabilities to the extent of the reinsurer's liability, improving its leverage ratio and expanding its capacity to write insurance. ${ }^{23}$ For life insurers, the result of the write-down is called the reserve credit taken, which represents estimated liabilities of the primary insurer that have been assumed by the reinsurer; and for $\mathrm{P}-\mathrm{C}$ insurers the account is called net amount recoverable from reinsurers. ${ }^{24}$ Because policyholder claims on an insurer are not affected by reinsurance, the insurer remains liable for the policyholder obligations if the reinsurer defaults even though the balance sheet credit for reinsurance can be substantial.

Life insurers ceded $\$ 60.4$ billion in premiums to non-affiliates and $\$ 78.1$ billion to affiliates in 2011, representing in total 20.2 percent of direct premiums written and 43.4 percent of surplus. P-C insurers ceded $\$ 69.6$ billion of premiums to non-affiliates and $\$ 38.8$ billion to affiliates, representing in total 21.6 percent of direct premiums and 18.9 percent of surplus. Hence life insurers' surplus exposure to reinsurance counterparty risk is higher than for P-C insurers, but counterparty risk from premiums ceded does not seem excessive for either type of insurer.

Reinsurance receivables represent about 12 percent of equity capital for life insurers and 7.5 percent of equity for P-C insurers. Hence, purely in terms of current receivables insurer equity is not seriously exposed to counterparty risk. However, when the reinsurance counterparty exposure for estimated future losses and benefits is included, the total is much higher. For life insurers, the reserve credit taken due to transactions with non-affiliated

${ }^{21}$ In a primary insurer cession, business underwritten by the insurer is ceded (or sold) to a reinsurer, with the primary insurer paying a fee (premium) to the reinsurer. In reinsurance assumed, the assuming insurer purchases business underwritten by another insurer for a premium.

${ }^{22}$ The term reinsurance receivables is used to refer to asset page item 16 in the NAIC life and P-C annual statements. It includes amounts receivable from reinsurers, funds held by or deposited with reinsured companies, and other amounts receivable under reinsurance contracts.

${ }^{23}$ U.S. insurers can take balance sheet credit for reinsurance as long as the reinsurer is "authorized," i.e., licensed in the ceding insurer's state of domicile, accredited in the ceding insurer's state of domicile, or licensed in a state with substantially similar credit for reinsurance laws. Insurers can take credit for unauthorized reinsurance only if the reinsurer posts collateral, in the form of funds held in the U.S. or letters of credit from U.S. banks. The NAIC and several individual U.S. states have begun to liberalize collateralization rules, and the process is ongoing.

${ }^{24}$ The difference between receivables, on the one hand, and reserve credit taken and net amount recoverable, on the other hand, is that receivables represent amounts currently owed and payable, whereas reserve credit taken and net amount recoverable largely represent estimated reserve liabilities for future losses. Reserve credit taken data for life insurers are from Schedule S on the NAIC annual statement, and reinsurance recoverables from P-C insurers are from Schedule F of the NAIC annual statement. 
reinsurers is 65.7 percent of surplus and the credit taken for affiliate reinsurance is 97 percent of surplus. P-C insurers are less exposed to non-affiliated reinsurers in terms of the net reinsurance recoverable than life insurers ( $25.3 \%$ of surplus) and have even less net exposure to affiliated reinsurers (14.9 percent of surplus). ${ }^{25}$ Thus, the degree of interconnectedness within the insurance industry due to reinsurance is significant, particularly for life insurance. However, this risk likely is not systemic in the sense of spilling over into other financial sectors. Cummins and Weiss (2012) provide more detailed concentration information for reinsurance from 2008. According to their results, at the median, P-C insurers cede 9.1 percent of direct and assumed premiums to the top four non-affiliated reinsurers. Concentration of recoverables in the top counterparties is high. The proportion of the total recoverables owed by the top one, four, and 10 counterparties at the median is 47.4 percent. 90.5 percent, and 100 percent, respectively. The Herfindahl index for recoverables at the median is 3,248 , approximately equivalent to having recoverables equally divided among three counterparties.

Exposure of surplus to reinsurance recoverable from non-affiliates varies widely across the P-C industry according to Cummins and Weiss (2012). At the median, exposure does not seem excessive - the ratio of reinsurance recoverables to surplus for all counterparties is 21 percent. At the $75^{\text {th }}$ percentile, reinsurance recoverable to surplus from all counterparties is $\mathbf{5 2 . 2}$ percent. Therefore, it appears from these statistics that at least one-fourth of P-C insurers could be seriously at risk if several large reinsurers were to fail.

Park and Xie (2011) conduct the first detailed examination on the likely impact of a major global reinsurer insolvency on the U.S. P-C insurance industry by running scenario analyses in which one of the top three reinsurers (Swiss Re, Munich Re, and Berkshire Hathaway) is allowed to become insolvent. They trace the effects of the reinsurer defaults as they flow through the industry, using financial statement data on reinsurance counterparty relationships. Even under an extreme assumption of a 100 percent reinsurance recoverable default by one of the top three global P-C reinsurers, only about two percent of U.S. P-C primary insurers would suffer financial ratings downgrades and only one percent of insurers would become insolvent. Hence, the potential for reinsurance problems in the P-C industry does not seem high.

The exposure to non-affiliated reinsurance counterparties in the life insurance industry is discussed in Cummins and Weiss (2012), also. Life insurance premium cessions are even more concentrated in the top counterparties than for P-C insurers. At the median, $53.0 \%$ of premiums are ceded to the top reinsurer, $93.5 \%$ to the top four reinsurers, and $100.0 \%$ to the top ten. The ratios of reserve credit taken to surplus at the median are not very high - e.g., $20.9 \%$ for the top four reinsurers and $24.5 \%$ for all reinsurers. However, a substantial proportion of companies in the industry have very high ratios of reserve credit taken to surplus - at the $75^{\text {th }}$ percentile, the ratio is $58.2 \%$ for the top reinsurer and $100.3 \%$ for the top four reinsurers. Thus, at least $25 \%$ of life insurers would find their surplus severely eroded if an intra-sector crisis developed in the reinsurance industry.

In conclusion, an insolvency crisis in the reinsurance market potentially could cause intra-sector problems in the insurance industry. Nevertheless, purely from their core activities, insurers are not sufficiently interconnected with non-insurance institutions such that the

\footnotetext{
${ }^{25}$ The SNL database used in compiling the reinsurance data nets out intra-group transactions.
} 
reinsurance problems would spill-over into the banking and securities industries. However, a reinsurance crisis could potentially cause spill-over risk due to interconnectedness of insurers and other institutions through insurers' non-core activities (and this is discussed later).

\section{Lack of Substitutability and Core Activities}

For an activity to pose a systemic threat to lack of substitutability, it is necessary not only that the activity not have substitutes but also that it is critical to the functioning of the economy. Banks pose substitutability problems because of their role in the payment and settlement systems, in transmitting central bank monetary policy, and in providing a critical source of liquidity and financing for consumers and businesses. Although insurance plays an important role in the economy, it does not suffer from lack of substitutability to the same extent as banking.

The bulk of financial transactions in life insurance relate to asset accumulation products rather than mortality/longevity risk bearing, and there are many substitutes for investing through life insurance annuities. For mortality/longevity risks, which are unique to insurance, many insurers are available to fill coverage gaps created by the failure of one or a few firms; and hedging mortality risk is not central to the economy as are payments-settlement or monetary policy. Thus, life insurance has substitutes and is not critical to the functioning of other firms.

Unlike life insurance, P-C insurance exists primarily to provide risk management and risk bearing services rather than serving an asset accumulation function. Certainly for individual insurance customers, there is no substitute for products such as automobile and homeowners insurance. However, even if the supply of individual P-C products was dramatically reduced, it is unlikely that real economic activity would be affected significantly. Even if several major insurers were to encounter severe financial difficulties, many other insurers are available to fill the coverage gap. The same would be true for small and medium-size commercial buyers. Large corporate buyers have many effective substitutes for $\mathrm{P}-\mathrm{C}$ insurance, including selfinsurance, captive insurance companies, and securitization of insurance-type risks. There has been considerable debate in the finance literature about whether widely held corporations should even buy insurance, other than to access the risk management and claims settlement expertise of insurers and perform other corporate risk management functions (MacMinn and Garven, 2000). Thus lack of substitutability does not seem to create a systemic risk as it relates to insurance. Because of the dominance of large insurers in the (non-UK) European market, substitutability may be more of a problem for P-C insurance there.

Nonetheless, some P-C insurance lines were harder hit by the financial crisis then other lines. These lines include errors and omissions (E\&O) insurance and directors and officers (D\&O) liability. AIG, Chubb, XL, and Lloyd's of London are large writers of these coverages. Estimating the cost of such claims is very difficult because claims are hard to prove. However, there appears to be no shortage of supply in these lines at the present time, although prices for these products have risen. Credit insurance is another type of coverage hit hard by the crisis. According to Baluch, Mutenga, and Parsons (2011), the economic downturn was reinforced by a decline in the supply of credit insurance. In fact, several governments, concerned about the availability of credit insurance, have taken actions to safeguard credit insurance and trading activity.

Of course, even for those functions that are unique to insurance, ease of entry into the 
insurance industry means that supply is unlikely to be disrupted for a significant period of time. Berry-Stoelzle, Nini, and Wende (2011) show that substantial new capital flowed into the life insurance industry in response to the financial crisis, and Cummins (2008) shows that there has been substantial entry into the P-C insurance market, particularly in Bermuda.

\section{Contributing Factors and Core Activities}

Except for some of the core activities of life insurers, most of the core activities of insurers generally do not lead to the identification of insurers as systemically important according to the primary indicators. Accordingly, the discussion of the contributing factors mainly relates to their role in creating financial vulnerabilities within the insurance industry. In this respect, we consider life and P-C insurers separately, except for regulation, where we discuss the regulatory framework more generally.

Leverage. Defining leverage as the ratio of capital-to-assets, P-C insurers are much more highly capitalized than life insurers or banks, and their capital-to-asset ratios have been increasing over time. The capital-to-asset ratio for P-C insurers was 27.8 percent in 1985, increasing to 39.6 percent by 2011. Of course, one reason P-C insurers hold more capital than life insurers or banks is that they are subject to catastrophe risk from events such as hurricanes and earthquakes. Life insurer capital-to-asset ratios are comparable to those of banks, both of which have been running at about 10 percent. Berry-Stoelzle, Nini, and Wende (2011) found that life insurers were able to recover quickly from losses sustained during the financial crisis by raising new capital, and insurer failure rates and guaranty fund assessments remain very low. Life insurers' reserve credit taken (162.7 percent of surplus on average) represents additional leverage that would come back onto life insurer balance sheets in the event of reinsurance failures. Thus, life insurers have the potential for significantly higher leverage due to reinsurer defaults. However, reinsurer defaults have not played a significant role historically in causing insurer insolvencies, and no such defaults occurred during the financial crisis.

Liquidity Risk. Life insurers have high liquidity risk due to their heavy investment in privately placed bonds. Total holdings of private placements represent 25.6 percent of life insurer bond portfolios and 209.5 percent of equity capital as of 2011. In addition, life insurers hold 26.5 percent of their bonds (19 percent of assets) in MBS and other ABS, including passthrough CMOs and REMICs. The amounts invested in MBS and ABS represent 216.6 percent of life insurer equity capital (policyholders surplus). Thus, MBS, ABS, and single issuer private placements represent 378.5 percent of life insurer surplus. These numbers are relevant because ABS and MBS were especially problematical during the financial crisis, and private placements are relatively illiquid.

Somewhat offsetting their asset liquidity risk, life insurers receive a significant amount of net cash from operations, defined as premiums plus investment income net of benefit payments, expenses, and taxes. Life insurers' net cash from operations represents 30.6 percent of benefit payments and 49.5 percent of equity capital as of 2011. Thus life insurers could withstand significant increases in benefit payments without liquidating assets, partially explaining their heavy concentration of investments in privately placed bonds. However, it is not clear whether the coverage of cash flow to surplus is sufficient to completely offset their asset liquidity risk.

P-C insurers are much less exposed to mortgage-backed securities and privately placed 
bonds. For P-C insurers, MBS and ABS securities represent only 30.6 percent of surplus, and private placements represent only 12.9 percent of surplus in 2011. Hence, life insurers face higher exposure to housing markets and significant asset liquidity risk, in comparison with $\mathrm{P}-\mathrm{C}$ insurers.

Complexity and Asset-Liability Mismatches. Life insurers also suffer from complexity, especially in terms of offering life insurance and annuity products with embedded options such as minimum interest rate guarantees. Life insurers are at least moderately exposed to optionability risk, due to the ability of policyholders to cash out their life insurance annuity policies. As mentioned, group annuities and separate accounts may be particularly susceptible to optionability risk, which may help to explain their association with systemic risk. The only contributing factor that does not seem to be a problem for life insurers is maturity risk, in that their asset and liability maturities seem to be well matched (see Cummins and Weiss, 2012, Table 4).

P-C insurers' core activities have low to moderate complexity, in comparison with complex banking products and life insurance products with embedded options. P-C insurers are vulnerable to catastrophe risk but have been able to withstand large catastrophes such as Hurricanes Andrew and Katrina in the past. P-C insurers' vulnerability to intra-sector crises appears low, although some insurers do have high exposure to non-affiliated reinsurance.

Government Regulation. U.S. insurance regulation prevented insurers from engaging in the dramatic increases in leverage that occurred for the shadow banks during the period preceding the crisis. The effectiveness of regulation is demonstrated by the low insurance insolvency rates in the U.S. Although U.S. regulation is "Balkanized" and the cumbersome regulatory structure often impedes necessary reforms, Federal bank regulators did not perform well in the period leading up to the financial crisis, and it is not clear that Federal regulators would be more effective than state regulators. Although the lack of a single overseer does create problems in managing multi-state insolvency risk (Acharya et al., 2009), nationally significant insurers are reviewed every quarter by the NAIC, and those that appear to be performing poorly are prioritized for further analysis by experienced regulators (The Financial Analysis Working Group).

Moral hazard could be created by the existence of insurance guaranty funds because guaranty fund premiums are not risk-based (Acharya et al., 2009). This feature of guaranty funds can lead to excessive risk-taking by insurers. However, moral hazard is mitigated somewhat by the fact that insurance guaranty funds have claim payment limits, giving policyholders an incentive to monitor insurers. Hence, relatively more market discipline is present for insurers than for other financial institutions such as banks (Harrington, 2009). Moreover, the NAIC's risk-based capital system penalizes insurers that take excessive risk, further reducing incentives for risk-taking.

\section{Systemic Risk and Non-Core Activities}

The core activities of P-C insurance companies involve providing various types of insurance coverage. The core activities of life insurers include providing asset accumulation products to consumers and businesses as well as insurance against mortality and longevity risk. In addition to their core products, insurers also have undertaken a variety of non-core activities. Some of these activities have the potential to create interconnectedness with other financial 
institutions and non-financial sectors of the economy and thereby foster systemic risk.

Although insurer involvement in non-core activities is usually associated with the passage of the Gramm-Leach-Bliley Act in 1999, insurers expanded their operations beyond traditional core insurance products decades earlier. ${ }^{26}$ Insurers have invested in privately placed bonds at least since the 1970s, in direct competition with the bond underwriting functions of investment banks; and also compete with banks in commercial mortgages. Life insurers introduced guaranteed investment contracts and single-premium deferred annuities in the 1970s, competing directly with bank certificates of deposit. Beginning in the 1970s, many insurers also introduced proprietary mutual fund families to compete with banks and securities firms. Insurers also engage in investment management for consumer and business clients. Following GrammLeach-Bliley, a few insurers also acquired or established thrift institutions to offer banking services. Insurers have expanded into the provision of financial guarantees, asset lending, and credit default swaps (CDS), as well as investing in ABS, MBS, and other complex structured securities. Insurers are active in trading derivatives such as foreign exchange and interest rate options. Insurers have entered the market for securitization, most prominently for catastrophelinked securities, but also for other types of risks. ${ }^{27}$ Some of these activities such as writing CDS and providing financial guarantees contribute to systemic risk, while others such as investing in MBS and ABS mainly increase the susceptibility of insurers to crises.

Detailed quantitative information on insurer non-core activities is not readily available. However, aggregate data on outstanding CDS by counterparty type are available from the Bank for International Settlements (BIS). The BIS data reveal that total CDS outstanding were \$58.2 trillion in the second half of 2007, declining to $\$ 29.9$ trillion by 2010 as a result of the financial crisis. The majority of CDS were held by reporting dealers, mainly large commercial and investment banks that have an active business with large customers (BIS, 2007). Insurers held $\$ 492$ billion in CDS outstanding in 2007 and $\$ 270$ billion in 2010. Thus, insurers have remained active in the CDS market even after the AIG debacle. Although insurers represent a small part of the CDS market, $\$ 270$ billion is a large exposure relative to industry capitalization.

Insurers can be at risk from selling CDS, but insurers also purchase protection products to hedge risk from their own investment holdings (bonds and stocks), exposing insurers to counterparty credit risk. CDS are frequently sold in the secondary market, so that a CDS may change hands many times (Baluch, Mutenga, and Parsons, 2011). It can turn out to be difficult to identify the counterparty to the trade in case of defaults so that unwinding the trade becomes difficult. Thus, insurers can experience significant credit risk, especially if the asset has a high notional value relative to assets.

Recent research on the stock prices of financial institutions provides evidence on the degree of interconnectedness within the financial industry. Billio et al. (2011) develop econometric measures of systemic risk and analyze stock price data on hedge funds, banks, brokers, and insurers for the period 1994-2008. They examine index returns on the four groups

\footnotetext{
${ }^{26}$ The Gramm-Leach-Bliley (Financial Services Modernization) Act repealed part of the Glass-Steagall Act of 1933, opening up the market among banks, securities firms and insurers. The Glass-Steagall Act prohibited any one institution from acting as any combination of an investment bank, a commercial bank, and an insurance company.

${ }^{27}$ Banks have also expanded into insurance and annuity markets. However, banks primarily serve as distributors of insurance products underwritten by unaffiliated insurance companies and not as insurance underwriters (Insurance Information Institute, 2011). Therefore, such expansion does not seem to have systemic implications.
} 
of financial institutions as well as the returns of the 25 largest entities in each group. They utilize principal components analysis to study the correlations among the four groups of institutions and Granger causality tests to analyze the direction of the relationships among the sample firms. They do not observe significant causal relationships between financial institutions in the first part of the sample period (1994-2000) but find that financial institutions have become significantly linked during the second part of the sample period (2001-2008). They find that the relationships are asymmetrical - the returns of banks and insurers have a more significant impact on hedge funds and brokers than vice versa. Insurers identified as systemically important include ACE, AIG, Progressive, and XL capital. The authors attribute the growing interrelationships among institutions to the existence of frictions in the financial system, including "value-at-risk constraints, transactions costs, borrowing constraints, costs of gathering and processing information, and institutional restrictions on short sales” (Billio et al., 2011, p. 10).

Acharya et al. (2010) develop an alternative measure of systemic risk, the systemic expected shortfall (SES), which gauges the propensity of a financial institution to be undercapitalized when the system as a whole is undercapitalized. Specifically, SES measures the amount by which a financial institution's capital drops below its target level conditional on the occurrence of a financial crisis. "SES is therefore the probability of an aggregate crisis times the conditional loss ... . in such a crisis. The important point is that the expectation is conditional on a macroeconomic shortfall” (Acharya et al., 2010, p. 14).

They analyze the stocks of the 102 financial institutions that had market capitalization exceeding \$5 billion as of June 2007 including four financial industry segments - depository institutions (29 firms), securities dealers and commodities brokers (10 firms), insurance companies (36 firms), and other financial institutions (27 firms). The period of analysis is 20062008. Their results indicated that "insurance firms are overall the least systemically risky, next were depository institutions and most systemically risky are the securities dealers and brokers," (p. 21). In terms of specific insurers, AIG appears "more systemic" than Berkshire Hathaway. They also point out that the top three insurance companies in terms of systemic risk (Genworth, Ambac, and MBIA) were heavily involved in providing financial guarantees for structured products in the credit derivatives market.

Billio et al. (2011) and Acharya et al. (2010) reveal that financial firms are highly interconnected and that insurance firms can be a source of systemic risk. These studies strongly suggest that the interconnectedness among institutions extends beyond exposure to common shocks. The analysis presented in our paper suggests that any systemic risk originating from the insurance sector is not attributable to the core activities of insurers with the exception of certain life insurance products. Rather, the interconnectedness between insurers and other financial firms is more likely attributable to the non-core or "bank-like" activities of insurers, particularly large, publicly traded firms. Also playing a role are the financial market frictions identified by Billio et al. (2011).

In the next section, the measure of systemic risk discussed in Acharya, Engle, and Richardson (2012), SRISK, is analyzed for a sample of insurer groups. Factors associated with SRISK are identified for purposes of understanding what may make insurers prone to systemic risk. 


\section{Statistical Analysis of Insurer Characteristics and a Measure of Systemic Risk}

In this section, correlation and regression analysis are conducted to determine the relationship between characteristics of an insurer sample and a measure of systemic risk, SRISK (Acharya, Engle, and Richardson, 2012). SRISK is defined as the expected capital shortfall of the firm in a financial crisis. It is related to SES but extracts the probability of a crisis occurring and focuses only on the expected capital shortfall (Acharya, Engle, and Richardson, 2012, p. 60). SRISK is estimated using data on daily equity returns on the stocks of financial firms and on a broad market index. Bivariate time series models are estimated using the daily stock return series. Simulations are then conducted to estimate the losses of equity capital in the event of future crises. A crisis is defined as a situation where the broad market index declines by 40 percent over the next six months (Acharya, Engle, and Richardson, 2012, p. 60-61).

Although the SRISK is commonly referred to as a measure of systemic risk, it cannot be used to distinguish between whether insurers are instigators of crises or merely victims of crises. That is, it only measures the extent to which a firm is undercapitalized when the market as a whole is undercapitalized. To determine whether insurers cause crises, a different type of analysis is necessary such as Granger causality. ${ }^{28}$ Nevertheless it is important for investors and regulators to understand how a firm will respond in a crisis (e.g., its tendency to be undercapitalized) regardless of who or what instigated the crisis. SRISK provides such a measure.

The data used in the analysis are described in the next section. The results of the statistical analysis are provided in the following section beginning with correlation analysis.

\section{Data}

Data for the analysis are obtained from various sources. Data on derivatives activity are hand collected from the 10K reports of insurers analyzed by Acharya et al. (2010). This includes the total fair value of derivatives, the notional amount of derivatives not used for hedging, the total notional amount of derivatives and the capital to asset ratio. NAIC data from insurers' annual statements are also obtained, particularly information on premiums by lines of business and investment allocations (e.g., amount of MBS) and whether the insurer is a life insurer, a P-C insurer, or conducts both types of business. These data are combined with data from Compustat which contains information on liabilities of the traded company. Finally, the measure of systemic risk (SRISK) and the beta for the traded company are obtained from New York University. ${ }^{29}$

\section{Correlation Analysis}

\footnotetext{
${ }^{28}$ Research by Chen et al. (2012) uses Granger causality tests to determine whether insurers create crises that spread to banks or vice-versa. The results indicate that insurers are much more significantly susceptible to crises that spread from banks rather than the other way around. The results show that shocks spreading from banks to insurers are possible based on the data analysis and that the impact is economically significant.

${ }^{29}$ The SRISK data are from the website: http://vlab.stern.nyu.edu/analysis/RISK.USFIN-MR.MES.
} 
We conducted correlation analysis between the SRISK systemic risk measure and insurer characteristics. Because SRISK is the conditional capital shortfall, it is dollar denominated and scaled to millions. As a robustness check, we also conducted the analysis with SRISK expressed as a ratio to equity capital. The results are similar so only the correlations with SRISK itself are shown in the tables.

The results of the correlation analysis are presented in Table 4. This table contains correlations between SRISK and different company characteristics, between SRISK and specific lines of business, and between SRISK and off-balance-sheet activities. Most of the variables discussed are expressed as ratios to equity capital. This is because it is the capital or equity of the insurer which is available to absorb adverse fluctuations from activities related to the variables included below. To help determine whether some lines of business are related to the systemic risk measure, the correlation between the proportion of premiums written in a line of business and the systemic risk measure is provided.

The size of an entity is typically associated with systemic risk. In the correlation analysis, the Ln (Assets) is positively and significantly related to the SRISK. Recall earlier that this variable was considered to be a primary factor associated with systemic risk for insurers, although it was also argued that insurer insolvencies are resolved in an orderly fashion with payouts continuing for years after the insolvency. Thus, overall Table 4 indicates that larger insurers are more sensitive to systemic risk. It should be kept in mind, however, that included in these assets amounts are all of the assets for all of the businesses that the insurer is involved in, including businesses such as banking. Therefore, the significant relation between SRISK and asset size may not mean that large insurers are actually systemically risky.

The systematic risk of the firm as proxied by the market equity beta of the firm is positively and significantly related to SRISK according to the table. A leverage measure (the ratio of capital-to-assets) is included in the correlation analysis, but this variable is not significant. Recall that leverage was considered to be a secondary or contributing factor to systemic risk rather than a primary factor. Two reinsurance variables are included in the correlation analysis - total reinsurance premiums ceded/equity capital and total reinsurance liabilities/equity capital. The premiums ceded variable is not significantly correlated with SRISK, but the ratio of reinsurance liabilities to capital is positively correlated with SRISK and significant at better than the one percent level. Thus, reinsurance exposure is associated with systemic risk for insurers.

Life insurers conduct many of their activities through the operation of separate accounts. The total amount of separate account assets relative to total insurer assets is positively and significantly related to SRISK. In separate accounts insurers may provide annuity products embedded with options, guaranteed investment products (GICs), and other banking type contracts. Therefore, it is not surprising that this characteristic of an insurer is significantly related to the systemic risk measure. 
Some of the large insurers in the sample also include banks within their holding company structure. The correlation analysis indicates that the ratio of banking customer deposits to equity capital is significantly and positively related to SRISK. Recall that Geneva Association (2010) argued that reliance on short term financing (such as commercial paper) could make an insurer systemically risky. Supporting this argument, the ratio of insurer commercial paper borrowings to equity capital is positively and significantly related to the SRISK. Finally, with respect to company characteristics, a significant and positive correlation between insurers operating in both life and P-C lines of business and SRISK exists. Perhaps this is because such insurers are more complex than insurers specializing in life or P-C insurance. The life insurer dummy variable is not significantly related to the systemic risk measure in the correlation analysis.

Table 4 also provides information about the relationship between lines of business and the systemic expected shortfall. Two measures of business line mix are included: line of business premiums divided by total equity and the proportion of premiums written in various business lines divided by total premiums. We first discuss the results with respect to the ratios of premiums to equity and then discuss the percentage business mix variables.

In terms of ratios of premiums written to equity capital, all four P-C line of business variables are statistically significant and negatively related to the SRISK. The negative relationships provide evidence to suggest that writing P-C lines may act as a stabilizing factor during systemic crises and reinforce the argument made by insurance industry representatives that P-C insurance is not systemic. The ratios of life insurance premiums to equity capital are statistically insignificant except for the group annuities variable, which is significant and positive. Thus, there is some evidence that writing group annuities is associated with systemic risk.

In terms of the variables measuring the percentages of premium volume by line, the P-C variables are negative and statistically significant, providing further evidence that $\mathrm{P}-\mathrm{C}$ insurance is not systemically risky. Three of four life insurance premium percentage variables are statistically significant and positive, providing further evidence that life insurance is associated with systemic risk. This is not surprising, considering that banks and life insurers both offer asset accumulation products and compete in many markets including pension plans and asset management.

Three variables are included in the analysis to measure non-core activities undertaken by insurers. These include the ratio of the notional amount of non-hedging derivatives, the total notional amount of derivatives, and the total fair value of derivatives. All three variables are measured as ratios to equity capital. All three variables have significant positive correlations with systemic risk SRISK. This reinforces the inference that non-core activities of insurers can create systemic risk.

Non-core risk also can be created when insurers rely on short-term sources of financing. As a measure of exposure to short-term financing risk, we include in the analysis the ratio of long-term debt due in one year to total liabilities. This measure has a significant positive correlation with SRISK, providing evidence that relatively short-term financing is associated 
with systemic risk.

In summary, several important insurer characteristics are significantly related to SRISK, including insurer size, the market equity beta, and separate accounts relative to assets. The ratio of group annuities to equity and three of four life insurance line of business percentage variables are positively correlated with systemic risk. Also notably, the P-C line of business variables are all negatively correlated with systemic risk. This suggests that life insurance products are associated with systemic risk but that P-C insurance products are not.

The correlation analysis in this section measures bivariate relationships. In the next section, several of these variables are included in multivariate regressions to see whether these variables are significantly related to systemic risk while controlling for other variables.

\section{Regression Analysis}

Ordinary-least-squares analysis was conducted based on our sample of insurers. Summary statistics for the variables in the regressions are shown in Table 5, and the regression results are presented in Table $6 .^{30}$ Table 6 indicates that size is significantly related to the systemic risk measure (SRISK) in the multivariate context, reinforcing the correlation analysis. ${ }^{31}$

However, after controlling for the other variables in the equation, the market equity beta is not statistically significant. The capital-to-asset variable was insignificant in the correlation analysis, and it is also insignificant in the regression results.

The ratio of MBS holdings to equity capital and the ratio of separate account assets to total assets are both positively and significantly related to the SRISK. The separate accounts result is consistent with the correlation analysis. Hence, being active in separate accounts and investing in MBS are positively associated with systemic risk.

To test for differences in systemic risk between life and $\mathrm{P}-\mathrm{C}$ insurance, a dummy variable is included in the regressions set equal to one if the firm conducts life insurance business and to zero otherwise. This variable is positive and significant in one of the two regression models shown in Table 6, providing some evidence that offering life insurance is associated with systemic risk but that writing $\mathrm{P}-\mathrm{C}$ insurance is not. ${ }^{32}$ Perhaps the life insurance dummy is insignificant in the second regression due to the presence of the group annuity proportion variable in this model. The dummy variable for offering both life and P-C insurance is not

\footnotetext{
${ }^{30}$ All of the variables contained in Table 4 could not be included in the regressions because of the limited number of observations of these variables vis-à-vis other variables. Notably, the variables with limited numbers of observations are the off-balance-sheet and customer deposits (bank) variables. Although the bivariate analysis is conducted on no fewer than 150 observations, when the off-balance-sheet variables were included in the regression analysis, the number of observations for the regressions was reduced to only about 50 . Hence the firms with offbalance-sheet data have missing values for other regression variables.

${ }^{31}$ The t-statistics in the regressions are robust to heteroskedasticity.

${ }^{32}$ The regression finding with respect to the life insurance dummy variable differs from the univariate correlation analysis, where this variable was not significantly related to SRISK.
} 
statistically significant. This provides some evidence that writing both types of insurance does not increase complexity to the extent of creating significant systemic risk.

The ratios of group annuity premiums and other liability premiums to equity capital are not statistically significant in the first regression. ${ }^{33}$ However, in the second regression, the ratio of group annuity premiums to total premiums is positive and significant at the one percent level. The ratio of other liability premiums to total premiums is not statistically significant in the second regression. Hence, the regressions provide further evidence that writing group annuities is positively associated with systemic risk but that writing $\mathrm{P}-\mathrm{C}$ insurance does not seem to create significant systemic risk. Thus, the core activities of P-C insurers do not seem to be systemically risky but both separate account and group annuity business for life insurers are associated with systemic risk.

Two reinsurance related variables are included in the regressions. The ratio of reinsurance premiums ceded to equity capital is insignificant in both regressions, consistent with the argument that reinsurance ceded is not systemically risky. However, the ratio of total reinsurance liabilities to equity capital is positive and highly significant in both regressions. This suggests that taking on significant reinsurance liabilities is positively associated with systemic risk. This could be because reinsurance exacerbates interconnectedness risk and/or because reinsurance is a relatively risky line of business. Future research on the nature of reinsurance assumed by insurers vis-a-vis systemic risk thus may be fruitful.

In summary, the regression results in Table 6 show that insurer size, the amount of MBS activity, and total reinsurance liabilities are all positively and significantly related to SRISK. The liability line of business variable for P-C insurers is not statistically significant. This is important because this line contains directors and officers (D\&O) liability and errors and omission (E\&O) business, which one might expect to be positively related to crises. However, the group annuity variable is significant in one of the regressions, reinforcing the inference that writing group annuities may be associated with systemic risk.

\section{Systemic Risk and U.S. Insurance Regulation}

The preceding analysis indicates that some characteristics of insurance groups are associated with the systemic risk measure. Therefore, regulators need to improve the effectiveness of group supervision. This is especially true for global insurance-led financial groups (Geneva Association, 2012). Large, global insurance groups have insurance subsidiaries that are regulated in the U.S. but also have financial subsidiaries located in other countries. Its London-based Financial Products division brought down AIG due to a failure of regulation, such that U.S. insurance regulators did not have jurisdiction and U.S. banking regulators failed to require adequate capitalization. ${ }^{34}$ The NAIC, IAIS, and other regulatory bodies are currently

\footnotetext{
${ }^{33}$ Other lines of business variables were also tested - both for life and P-C - but these were never significant in either regression.

${ }^{34}$ AIGFP was under the regulatory authority of the U.S. Office of Thrift Supervision (OTS). In retrospect, it is clear that OTS oversight was not adequate to prevent AIGFP's financial difficulties.
} 
working on improvements in group supervision. Because of the importance of non-core activities in potentially creating systemic risk, it is useful to review the present and proposed future status of insurance group regulation. We focus primarily on the U.S. and briefly mention international efforts. The section below considers proposed/actual changes in state regulation and federal regulation, and concludes by providing a few recommendations for future regulation.

\section{State Insurance Regulation}

Historically, U.S. insurance regulation has focused on the operations and financial results of insurers on a legal entity basis, i.e., most regulatory efforts have targeted individual insurers that are members of groups and unaffiliated single insurers rather than insurance groups. However, two NAIC model laws specifically relate to insurance holding companies. They are Model Law (ML) 440, Insurance Holding Company System Regulatory Act, and ML 450, Insurance Holding Company System Model Regulation with Reporting Forms and Instructions. In light of the financial crisis, modifications to these laws have been proposed, and holding company analysis became an accreditation requirement effective January 1, 2012. A new proposed model law with implications for group supervision, the Risk Management and Own Risk and Solvency Assessment (RMORSA) Model Law is also under consideration. We first consider the present regulatory rules under MLs 440 and 450 and then consider the proposed revisions to those laws and the key provisions of RMORSA as they relate to insurance groups.

An important objective of MLs 440 and 450 is to regulate transactions within the insurance group. Under ML 440, every insurer which is a member of an insurance holding company is required to register with the insurance commissioner. Transactions within an insurance holding company system to which a registered insurer is a party must satisfy legally specified requirements. Among other things, the terms of transactions within the holding company must be reasonable and fair. Pre-notification to the state commissioner and commissioner approval is required for specified transactions involving a registered insurer and any person in its holding company system. Such specified transactions include large sales, purchases, exchanges, loans, or investments; significant modification of reinsurance agreements; and any material transactions which the commissioner believes may adversely affect the interests of the insurer's policyholders. In addition, registered insurers must provide annual information in a prescribed format including capital structure, financial condition, the identity and relationship of every member of the insurance holding company as well as outstanding transactions and agreements between the insurer and its affiliates.

ML 450 is primarily directed towards providing rules and procedures necessary to carry out ML 440. Among other provisions, ML 450 requires insurance groups to file an annual "Insurance Holding Company Registration Statement." In the Registration Statement, the holding company is required to report a variety of information including disclosures regarding purchases, sales, or exchanges of assets; litigation or administrative proceedings pending or concluded within the past year; and financial statements and exhibits. In conclusion, currently existing model laws require the commissioner to be informed of material actions/transactions that affect domestically authorized insurers within insurance holding companies, including transactions with non-insurance affiliates, but commissioners do not have the authority to order an insurance subsidiary to provide other information on non-insurance affiliates.

State commissioners can take no direct action against non-insurance affiliates within an 
insurance holding company. However, state commissioners can place pressure on regulated insurance subsidiaries concerning holding company activities and the activities of non-insurance affiliates, e.g., state commissioners can place pressure so that the books and records of affiliates are provided to the commissioner. In particular, state insurance commissioners could have inquired about the activities of AIG Financial Products (AIGFP) even though AIGFP was not regulated by the state commissioners. If any resulting disclosures had raised questions about threats to the financial condition of AIG's regulated U.S. insurance subsidiaries, U.S. regulators could have tightened regulatory requirements on the U.S. subsidiaries, including requiring the subsidiaries to operate with increased capital.

Revisions to MLs 440 and 450 have been proposed and have already been adopted by nine states. ${ }^{35}$ The overall focus of the proposed revisions is on enterprise risk management (ERM), corporate governance, and increasing regulatory authority to obtain information and regulate the activities of insurance holding companies. The most important change is the introduction of new guidelines for reporting enterprise risk (a required annual Enterprise Risk Report (ERR)). The ERR must indicate (among other things) any material developments regarding strategy, internal audit findings, compliance, or risk management that, in the opinion of senior management, could adversely affect the insurance holding company system. Under the revised model laws, the commissioner may order any registered insurer to produce records, books, or other information that are deemed reasonably necessary to determine the financial condition of the insurer, including information on non-insurance affiliates.

The Risk Management and Own Risk and Solvency Assessment (RMORSA) Model Act is a new model law, tentatively scheduled for implementation in 2015. The purpose of the model law is to provide the requirements for maintaining a risk management framework and to provide instructions for filing an annual ORSA Summary Report with the insurance commissioner. The ORSA requirement applies to the insurer or the insurance group of which the insurer is a member. At a minimum, the ORSA Summary Report should describe the risk management framework and provide an assessment of risk exposure, group risk capital adequacy, and prospective solvency assessment. The Report is to be supported by internal risk management materials and more detailed documentation. The goals of ORSA are to foster an effective level of ERM for all insurers and to provide a group-level perspective on risk management and capital.

The revisions to MLs 440 and 450 along with the Risk Management and ORSA Model Act should provide insurance commissioners more complete information on the risks facing insurance holding companies. The Enterprise Risk Report and the ORSA Summary Report, especially, should be instrumental in achieving this goal. The revisions to ML 440 clarify and strengthen regulatory authority to require information about non-insurance affiliates within an insurance holding company. The state insurance commissioner still would not have any direct control over non-insurance affiliates or affiliates outside of its geographic jurisdiction, but pressure can be brought to bear on the regulated affiliate if the state commissioner believes problems exist elsewhere in the group.

The revisions of MLs 440 and 450 strengthen regulatory authority over insurance holding companies and facilitate bringing pressures on regulated insurance subsidiaries to prevent spillovers of financial problems from non-insurance affiliates. However, because insurance in

\footnotetext{
${ }^{35}$ The revised model laws have been put out for comment until the end of 2012. Whether the revised model laws become a requirement for accreditation will be decided after that.
} 
the U.S. is regulated by 51 separate jurisdictions, regulators need to carefully monitor the noninsurance subsidiaries of insurance-led groups and coordinate efforts to communicate any danger signals across regulatory jurisdictions. In addition, regulators need to develop stronger groupwide supervision to monitor primary indicators and contributing factors such as interconnectedness, leverage, and liquidity risk to prevent future systemic events.

\section{Federal Regulation}

An important new regulatory agency with potential authority over insurance holding companies is the Financial Stability Oversight Council (FSOC) established by the Dodd-Frank Wall Street Reform and Consumer Protection Act of 2010. The FSOC has three primary purposes (FSOC, 2012): (1) To identify risks to the financial stability of the U.S. that could arise from the activities of large, interconnected bank holding companies or nonbank financial companies (emphasis added). (2) To promote market discipline, by eliminating expectations on the part of shareholders, creditors, and counterparties of such firms that the U.S. government will shield them from losses in the event of failure. (3) To respond to emerging threats to the stability of the U.S. financial system.

The FSOC has established a three-stage process for designating a nonbank financial institution as a systemically important financial institution (SIFI). Stage 1 stipulates that the institution will be subject to further analysis if it has at least $\$ 50$ billion of consolidated financial assets and meets or exceeds any one of several additional quantitative thresholds, including \$30 billion in gross notional credit default swaps for which the nonbank financial company is the reference entity, $\$ 3.5$ billion in derivative liabilities, or $\$ 20$ billion of total debt outstanding. In Stage 2, the FSOC will further analyze those companies triggering the Stage 1 thresholds using a broad range of information from existing public and regulatory sources. The final step, Stage 3, involves direct contact by the FSOC with each nonbank financial institution that has passed through Stages 1 and 2 of the SIFI process to request additional information from the company. At the end of Stage 3, the FSOC makes a final determination about designating the company as a SIFI. Institutions designated as SIFIs come under the regulatory authority of the Federal Reserve, which can impose "enhanced supervision and prudential standards, whether they are banks or nonbanks, and the ability to subject key market infrastructure firms to heightened riskmanagement standards” (U.S. Department of the Treasury, 2012) (emphasis added).

As of early March 2013, the FSOC had designated no nonbanks as SIFIs, although it had designated eight financial market utilities (FMUs) as systemically important, including the Clearinghouse Payments Company and ICE Clear Credit. ${ }^{36}$ Nevertheless, the FSOC clearly has the authority to designate non-bank financial institutions as SIFIs and subject them to additional regulation. As of the end of 2011, the top 26 U.S. life insurance groups all exceeded the $\$ 50$ billion asset threshold under the SIFI Stage 1 criterion, but only five predominantly P-C groups exceeded the threshold (A.M. Best Company, 2012a, 2012b). It remains to be seen whether SIFI rules will be vigorously applied to nonbank financial institutions. ${ }^{37}$

\footnotetext{
${ }^{36}$ AIG is expected to be declared a systemically important financial institution sometime in 2013.

${ }^{37}$ Another regulatory initiative that may have some relevance for U.S. insurance groups is the effort by the IAIS to identify globally systemically important insurers (GSIIs) (see IAIS, 2012). This effort is in response to the task set by the G20 and the Financial Stability Board. The proposed assessment of GSIIs involves three steps: collection of data, methodological assessment of the data, and a supervisory judgment and validation process. However, because
} 


\section{Issues to Consider for Future Regulation}

In summary, the key to effective insurance regulation is to design a regulatory system that effectively encompasses both the core and non-core enterprises of the insurance sector and coordinates regulation across national boundaries. Given the limited information currently available on derivatives, asset lending, and other non-core activities of insurers, regulators should require more disclosure of these types of transactions. Disclosure enhances transparency and hence reduces the probability of the development of systemic crises. Regulators should also have the authority to regulate leverage by non-core subsidiaries of insurance firms.

In addition, large companies need a consolidated federal or state supervisor; for example, before the crisis, there was no single supervisor examining and regulating all aspects of AIG. But the supervision provided should focus only on those areas that relate to systemic risk. This will allow for the operation of a competitive market for insurers (and other financial institutions) with respect to non-systemic activities.

In tandem with the appointment of a consolidated supervisor, resolution of large insurance groups should be considered. Under the present system, the state insurance regulator regulates insurance and the guaranty fund system is state-based. If an additional layer of regulation is added with a consolidated supervisor, should a consolidated guaranty structure be added for the activities regulated by the consolidated supervisor? The issue of who would bear the responsibility for the insolvency of a large national group that is regulated by both the state and a consolidated (federal) regulator arises.

New regulation should also be focused; a blanket approach should not be used. For example, blanket increases in the amount of capital that systemically important financial institutions need to hold will not necessarily make financial institutions safer or the economy stronger. That is, financial institutions designated as systemically risky can increase the riskiness of their activities in response to capital requirements, or other financial institutions not designated as systemically risky can begin to undertake systemically risky activity. Market disruptions for some products might also occur if capital requirements for the largest insurers are increased in an across the board, ad hoc fashion. Finally, it should be mentioned that AIG Group’s problems were mostly liquidity related rather than capital-induced.

Any new requirements (especially capital requirements for systemically important institutions) should specifically complement existing state regulatory requirements. It is worth keeping in mind that under the existing U.S. state regulatory framework, insurers fared well through the crisis. New regulation should not fix what is not broken.

New regulation should also be consistent with new global regulation likely to emanate from the IAIS. That is, U.S. insurers should not be placed at a global disadvantage. Further, if an international consolidated group supervisor is chosen for large groups, new issues would be created. For example, the question of who would bear the responsibility for failed insurance groups, and how assets of an insolvent group would be distributed among countries in which the global group operated would need to be considered.

the IAIS has no direct statutory authority over insurers in particular countries, any regulatory consequences of an insurer's identification as a GSII would have to be implemented by national regulatory organizations. Further analysis of the identification of SIFIs in insurance is provided in Geneva Association (2011). 
One issue that would need to be resolved globally is the accounting system that insurers use. There is increasing pressure by federal regulators for insurers to use GAAP accounting (in addition to or in replacement of) statutory accounting. This requirement for U.S. insurers would be costly. Nevertheless, what is needed is a reporting system that allows all operations of the group to be consolidated together so that insurers' and groups' financial results can be compared internationally.

\section{Conclusion}

The primary conclusion of the paper is that most of the core activities of the U.S. insurers are not associated with systemic risk. This is particularly true for P-C insurance because there is evidence that writing P-C insurance is inversely related to the SRISK, an important measure of systemic risk. Although there are no substitutes for personal lines and small business P-C insurance, even the failure of several large P-C insurers would not significantly disrupt the market because many other insurers would be able to step in to fill coverage gaps. P-C insurers for the most part are not sufficiently large or inter-connected with other parts of the financial sector to create systemic risk through their core activities.

We do find some evidence that some core activities of life insurers, particularly separate accounts and group annuities, are positively associated with systemic risk. This is consistent with the observation that life insurance products are similar to banking products in many respects and that life insurers compete with banks in many categories of products. There is also some evidence that insurer investments in mortgage backed securities (MBS) are associated with systemic risk. The use of MBS is more prevalent among life insurers than among P-C insurers.

We emphasize, however, the susceptibility to systemic risk is not equivalent to the propagation of systemic risk. Chen et al. (2012) provide evidence that banks create economically significant systemic risk for insurers but not vice versa. Hence, insurers tend to be the victims rather than the propagators of systemic risk. This is an important distinction that should be kept clearly in mind in developing any new insurance regulations.

Based on our analysis of susceptibility to intra-sector crises, we find that life insurers are more vulnerable to crises than P-C insurers. Life insurers are more highly levered than P-C insurers and are exposed to credit and liquidity risk due to their heavy investment in MBS and privately placed bonds. They also offer complex financial products with embedded derivatives. Nevertheless, insolvency rates in the life insurance industry remain low, and life insurers weathered the financial crisis successfully in spite of their exposure to ABS/MBS. Life insurers also demonstrated the ability to recapitalize quickly following the worst of the financial crisis.

Both life and P-C insurers are potentially vulnerable to reinsurance crises and spirals because of their exposure to reinsurance counterparty credit risk, the main source of interconnectedness for insurers. Because reinsurance counterparty credit risk is highly concentrated, a reinsurance spiral potentially could be triggered by the failure of one or more leading reinsurers, triggering an insolvency crisis in the insurance industry. Nevertheless, recent research provides evidence that the failure of a large reinsurer would be minimally disruptive to the U.S. P-C insurance market, and reinsurance failures historically have not been an important causal factor in insurance insolvencies. We find that regulation is not an important source of sectoral risk with respect to insurer core activities. 
As was demonstrated by the AIG debacle, the non-core activities of insurers can constitute a potential source of systemic risk, and interconnectedness among financial firms has grown significantly in recent years. Non-core activities include trading in derivatives (such as credit default swaps), asset lending, asset management, and providing financial guarantees. Statistical analysis indicates that factors such as derivatives trading, investing in ABS and life insurer separate account activity are associated with a measure of systemic risk-the systemic expected shortfall.

Most of the non-core activities conducted by insurers are beyond the traditional purview of insurance regulators and have not been rigorously regulated by banking authorities. Therefore, on a worldwide scale, regulators need to significantly improve their capabilities in group supervision. In the U.S., regulators have some authority to tighten capital requirements and other regulations for regulated insurers deemed vulnerable due to the activities of noninsurance affiliates. Under proposed revisions to regulatory laws, regulators would have broad authority to require disclosures of information on the activities of non-insurance subsidiaries of insurance holding companies. Consequently, if the revisions are adopted, U.S. regulators will have the information to prevent another AIG-type crisis, although they still will not have direct authority over non-insurance subsidiaries. 


\section{References}

Acharya, Viral V, John Biggs, Matthew Richardson, and Stephen Ryan, 2009, “On the Financial Regulation of Insurance Companies,” working paper, NYU Stern School of Business, New York.

Acharya, Viral V., Lasse H. Pedersen, Thomas Philippon, and Matthew Richardson, 2010, “Measuring Systemic Risk,” working paper, Federal Reserve Bank of Cleveland, Cleveland, OH.

Acharya, Viral V., Robert Engle, and Matthew Richardson, 2010, “Capital Shortfall: A New Approach to Ranking and Regulating Systemic Risks,” American Economic Review 102: 59-64,

American International Group, 2009, AIG: Is the Risk Systemic? (New York).

A.M. Best Company, 2012a, Best's Aggregates and Averages: Life/Health - 2012 Edition (Oldwick, NJ).

A.M. Best Company, 2012b, Best’s Aggregates and Averages: Property/Casualty - 2012 Edition (Oldwick, NJ).

A.M. Best Company, 2012c, U.S. Life/Health - 1969-2011 Impairment Review (Oldwick, NJ).

A.M. Best Company, 2012d, U.S. Property/Casualty -1969-2011 P/C Impairment Review (Oldwick, NJ).

Baluch, Faisal, Stanley Mutenga, and Chris Parsons, 2011, “Insurance, Systemic Risk, and the Financial Crisis,” The Geneva Papers 36: 126-163.

Bank for International Settlements (BIS), 2003, A Glossary of Terms Used in Payments and Settlements Systems (Basel, Switzerland). http://www.bis.org/publ/cpss00b.pdf?noframes=1

Bank for International Settlements (BIS), 2007, Triennial Central Bank Survey: Foreign Exchange and Derivatives Markets in 2007 (Basel, Switzerland).

Bell, Marian and Benno Keller, 2009, Insurance and Stability: The Reform of Insurance Regulation, (Zurich, Switzerland: Zurich Financial Services Group).

Berry-Stolzle, Thomas R., Gregory P. Nini, and Sabine Wende, 2011, "External Financing in the Life Insurance Industry: Evidence from the Financial Crisis," working paper, University of Georgia, Athens, GA.

Billio, Monica, Mila Getmansky, Andrew W. Lo, and Loriana Pelizzon, 2011, "Econometric Measures of Connectedness and Systemic risk in the Finance and Insurance Sectors,” MIT Sloan Research Paper 4774-10, Cambridge, MA.

Brunnermeier, Markus K., 2009, “Deciphering the Liquidity and Credit Crunch: 2007-2008,” Journal of Economic Perspectives 23: 77-100.

Brunnermeier, Markus K. and Lasse Heje Pedersen, 2009, “Market Liquidity and Funding 
Liquidity,” The Review of Financial Studies 22 (6): 2201-2238.

Chen, Hua, J. David Cummins, Krupa S. Viswanathan, and Mary A. Weiss, 2012, "Systemic Risk and the Inter-Connectedness between Banks and Insurers: An Econometric Analysis," Journal of Risk and Insurance, forthcoming.

Cummins, J. David, 2007, "Reinsurance for Natural and Man-Made Catastrophes in the United States: Current State of the Market and Regulatory Reforms," Risk Management and Insurance Review 10: 179-220.

Cummins, J. David, 2008, The Bermuda Insurance Market: An Economic Analysis (Hamilton, Bermuda: Bermuda Insurance Market), www.bermuda-insurance.org.

Cummins, J. David and Mary A. Weiss, 2000, "The Global Market for Reinsurance: Consolidation, Capacity, and Efficiency,” Brookings-Wharton Papers on Financial Services: 2000: 159-222.

Cummins, J. David and Mary A. Weiss, 2012, Systemic Risk and the Insurance Industry,” working paper, Temple University, Philadelphia.

Financial Stability Board, 2009, Guidance to Assess the Systemic Importance of Financial Institutions, Markets and Instruments: Initial Considerations (Basel, Switzerland).

Gallanis, Peter G., 2009, "NOLHGA, the Life and Health Insurance Guaranty System, and the Financial Crisis of 2008-2009," available at http://www.nolhga.com/factsandfigures/main.cfm

Geneva Association, 2010, Systemic Risk in Insurance: An Analysis of Insurance and Financial Stability (Geneva, Switzerland).

Geneva Association, 2011, Considerations for Identifying Systemically Important Financial Institutions in Insurance (Geneva, Switzerland).

Geneva Association, 2012, Insurance and Resolution in Light of the Systemic Risk Debate (Geneva, Switzerland).

Grace, Martin F., 2010, “The Insurance Industry and Systemic Risk: Evidence and Discussion,” working paper, Georgia State University, Atlanta, GA.

Group of Ten, 2001, Report on Consolidation in the Financial Sector (Basel, Switzerland: Bank for International Settlements).

Group of Thirty, 2006, Reinsurance and International Financial Markets (Washington, D.C.).

Harrington, Scott E., 2009, “The Financial Crisis, Systemic Risk, and the Future of Insurance Regulation,” The Journal of Risk and Insurance 76 (4): 785-819.

International Association of Insurance Supervisors (IAIS), 2009, Systemic Risk and the 
Insurance Sector (Basel, Switzerland).

International Association of Insurance Supervisors (IAIS), 2012, Global Systemically Important Insurers: Proposed Assessment Methodology (Basel, Switzerland).

International Monetary Fund (IMF), 2009, Global Financial Stability Report, Responding to the Financial Crisis and Measuring Systemic Risks (Washington, D.C.).

Insurance Information Institute, 2012, Financial Services Fact Book (New York, NY).

Kaufman, George G. and Kenneth E. Scott, 2003, "What is Systemic Risk, and Do Bank Regulators Retard or Contribute to It?”, The Independent Review 7 (3): 371-391.

MacMinn, Richard and James Garven, 2000, “On Corporate Insurance,” in Georges Dionne, ed., Handbook of Insurance (Boston: Kluwer Academic Publishers).

National Association of Insurance Commissioners (NAIC), 2011, Capital Markets Special Report, May 20, 2011 (New York, NY: NAIC Capital Markets Group).

National Conference of Insurance Guaranty Funds (NCIGF), 2011, “Testimony for the Record on the National Conference of Insurance Guaranty Funds Before the House Financial Services Subcommittee on Insurance, Housing, and Community Opportunity," Washington, DC, November 16, 2011 (http://www.ncigf.org/).

Neyer, J. Steven, 1990, “The LMX Spiral Effect,” Best’s Review 91 (July): 62ff.

O’Neill, William, Nilam Sharma, and Michael Carolan, 2009, "Coping with the CDS Crisis: Lessons Learned from the LMX Spiral,” Journal of Reinsurance 16: 1-34.

Park, Sojung C. and Xiaoying Xie, 2011, "Reinsurance and Systemic Risk: The Impact of Reinsurer Downgrading on Property-Casualty Insurers," working paper, California State University, Fullerton.

Pozsar, Richard, Tobias Adrian, Adam Ashcraft, and Hayley Boesky, 2010, "Shadow Banking," Federal Reserve Bank of New York Staff Report No. 458 (New York: NY).

Standard \& Poor’s, 2012, Industry Surveys: Banking (New York, NY).

Standard \& Poor’s, 2012, Industry Surveys: Insurance - Life \& Health (New York, NY).

Swiss Re, 2003, Reinsurance - A Systemic Risk?, Sigma No. 5/2003 (Zurich, Switzerland).

United States, Department of Commerce, Bureau of Economic Analysis (BEA), 2012, National Economic Accounts (Washington, DC). http://bea.gov/national/nipaweb/Index.asp.

United States, Department of the Treasury, Financial Stability Oversight Council (FSOC), 2012, 2012 Annual Report (Washington, DC). 
Table 1

Holdings of Financial Assets By Insurers and Commercial Banks

\begin{tabular}{|c|c|c|c|c|c|}
\hline Asset/Holdings & 2007 & 2008 & 2009 & 2010 & 2011 \\
\hline Treasury Securities & $5,099,199$ & $6,338,184$ & $7,781,929$ & $9,361,488$ & $10,428,308$ \\
\hline Banks* & $2.2 \%$ & $1.5 \%$ & $2.3 \%$ & $3.0 \%$ & $2.3 \%$ \\
\hline Property-Casualty Insurers & $1.4 \%$ & $1.0 \%$ & $1.1 \%$ & $1.0 \%$ & $0.9 \%$ \\
\hline Life Insurers & $1.4 \%$ & $1.7 \%$ & $1.7 \%$ & $1.7 \%$ & $1.6 \%$ \\
\hline Agency \& GSE Securities & $7,397,749$ & $8,166,697$ & $8,106,793$ & $7,598,157$ & $7,577,392$ \\
\hline Banks* & $16.1 \%$ & $16.1 \%$ & $18.1 \%$ & $20.6 \%$ & $22.0 \%$ \\
\hline Property-Casualty Insurers & $1.7 \%$ & $1.4 \%$ & $1.4 \%$ & $1.5 \%$ & $1.6 \%$ \\
\hline Life Insurers & $5.2 \%$ & $4.5 \%$ & $4.6 \%$ & $4.9 \%$ & $5.1 \%$ \\
\hline Municipal Securities & $3,448,076$ & $3,543,420$ & $3,697,882$ & $3,795,591$ & $3,743,366$ \\
\hline Banks* & $5.9 \%$ & $6.3 \%$ & $6.2 \%$ & $6.8 \%$ & $8.0 \%$ \\
\hline Property-Casualty Insurers & $10.8 \%$ & $10.8 \%$ & $10.0 \%$ & $9.2 \%$ & $8.8 \%$ \\
\hline Life Insurers & $1.2 \%$ & $1.3 \%$ & $2.0 \%$ & $3.0 \%$ & $3.3 \%$ \\
\hline Corporate and Foreign Bonds & $11,543,006$ & $11,118,323$ & $11,576,850$ & $11,538,517$ & $11,586,995$ \\
\hline Banks* & $9.4 \%$ & $9.5 \%$ & $7.9 \%$ & $6.8 \%$ & $6.8 \%$ \\
\hline Property-Casualty Insurers & $2.5 \%$ & $2.4 \%$ & $2.6 \%$ & $2.8 \%$ & $3.1 \%$ \\
\hline Life Insurers & $16.1 \%$ & $16.3 \%$ & $16.6 \%$ & $17.6 \%$ & $18.4 \%$ \\
\hline Corporate Equities & $25,580,900$ & $15,640,457$ & $20,123,185$ & $23,249,520$ & $22,522,227$ \\
\hline Banks* & $0.3 \%$ & $0.2 \%$ & $0.3 \%$ & $0.3 \%$ & $0.3 \%$ \\
\hline Property-Casualty Insurers & $0.9 \%$ & $1.2 \%$ & $1.1 \%$ & $0.9 \%$ & $1.0 \%$ \\
\hline Life Insurers & $5.7 \%$ & $6.4 \%$ & $6.0 \%$ & $6.0 \%$ & $6.4 \%$ \\
\hline Multifamily Residential Mortgages & 784,628 & 837,675 & 846,965 & 837,772 & 844,214 \\
\hline Banks* & $33.3 \%$ & $33.5 \%$ & $32.0 \%$ & $30.8 \%$ & $29.8 \%$ \\
\hline Property-Casualty Insurers & $0.0 \%$ & $0.0 \%$ & $0.0 \%$ & $0.0 \%$ & $0.0 \%$ \\
\hline Life Insurers & $6.6 \%$ & $6.2 \%$ & $5.7 \%$ & $5.6 \%$ & $5.9 \%$ \\
\hline Commercial Mortgages & $2,447,855$ & $2,566,445$ & $2,478,077$ & $2,314,001$ & $2,232,357$ \\
\hline Banks* & $54.9 \%$ & $56.8 \%$ & $57.3 \%$ & $57.0 \%$ & $56.2 \%$ \\
\hline Property-Casualty Insurers & $0.2 \%$ & $0.2 \%$ & $0.2 \%$ & $0.2 \%$ & $0.2 \%$ \\
\hline Life Insurers & $10.3 \%$ & $10.4 \%$ & $10.4 \%$ & $10.9 \%$ & $11.8 \%$ \\
\hline
\end{tabular}

*Includes U.S. chartered depository institutions, foreign banking offices in the U.S., and banks in U.S.

affiliated areas. Credit unions are excluded.

Note: Asset holdings are in millions of dollars.

Source: Federal Reserve Flow of Funds Accounts (Washington, DC: Board of Governors of the Federal Reserve System). 
Table 2

Solvency Record and Guaranty Fund Assessments: 1988-2010

Life-Health

Property-Casualty

\begin{tabular}{|c|c|c|c|c|c|c|c|c|}
\hline Year & $\begin{array}{l}\text { No. of } \\
\text { Failures }\end{array}$ & $\begin{array}{l}\text { Failure } \\
\text { Rate }\end{array}$ & $\begin{array}{c}\text { Assessments } \\
\text { (\$ millions) }\end{array}$ & $\begin{array}{l}\text { Assessments } \\
\% \text { of Premiums }\end{array}$ & $\begin{array}{l}\text { No. of } \\
\text { Failures }\end{array}$ & $\begin{array}{l}\text { Failure } \\
\text { Rate }\end{array}$ & $\begin{array}{l}\text { Assessments } \\
\text { (\$ millions) }\end{array}$ & $\begin{array}{l}\text { Assessments } \\
\% \text { of Premuims }\end{array}$ \\
\hline 1988 & 27 & $1.02 \%$ & $\$ 80$ & $0.0351 \%$ & 48 & $1.46 \%$ & $\$ 465$ & $0.2298 \%$ \\
\hline 1989 & 55 & $2.04 \%$ & $\$ 103$ & $0.0421 \%$ & 49 & $1.48 \%$ & $\$ 714$ & $0.3418 \%$ \\
\hline 1990 & 47 & $1.77 \%$ & $\$ 198$ & $0.0748 \%$ & 55 & $1.66 \%$ & $\$ 434$ & $0.1988 \%$ \\
\hline 1991 & 82 & $3.14 \%$ & $\$ 529$ & $0.2006 \%$ & 60 & $1.77 \%$ & $\$ 435$ & $0.1948 \%$ \\
\hline 1992 & 39 & $1.56 \%$ & $\$ 735$ & $0.2607 \%$ & 59 & $1.72 \%$ & $\$ 384$ & $0.1685 \%$ \\
\hline 1993 & 25 & $1.05 \%$ & $\$ 632$ & $0.1977 \%$ & 41 & $1.18 \%$ & $\$ 520$ & $0.2152 \%$ \\
\hline 1994 & 12 & $0.54 \%$ & $\$ 843$ & $0.2493 \%$ & 28 & $0.80 \%$ & $\$ 498$ & $0.1985 \%$ \\
\hline 1995 & 11 & $0.52 \%$ & $\$ 876$ & $0.2493 \%$ & 16 & $0.46 \%$ & $\$ 67$ & $0.0256 \%$ \\
\hline 1996 & 20 & $0.98 \%$ & $\$ 574$ & $0.1519 \%$ & 12 & $0.35 \%$ & $\$ 95$ & $0.0355 \%$ \\
\hline 1997 & 18 & $0.94 \%$ & $\$ 448$ & $0.1104 \%$ & 32 & $0.92 \%$ & $\$ 236$ & $0.0854 \%$ \\
\hline 1998 & 12 & $0.63 \%$ & $\$ 275$ & $0.0620 \%$ & 17 & $0.53 \%$ & $\$ 239$ & $0.0843 \%$ \\
\hline 1999 & 26 & $1.38 \%$ & $\$ 167$ & $0.0341 \%$ & 20 & $0.63 \%$ & $\$ 179$ & $0.0620 \%$ \\
\hline 2000 & 9 & $0.48 \%$ & $\$ 149$ & $0.0275 \%$ & 48 & $1.53 \%$ & $\$ 306$ & $0.1012 \%$ \\
\hline 2001 & 9 & $0.48 \%$ & $\$ 129$ & $0.0268 \%$ & 49 & $1.59 \%$ & $\$ 713$ & $0.2168 \%$ \\
\hline 2002 & 10 & $0.55 \%$ & $\$ 71$ & $0.0138 \%$ & 47 & $1.54 \%$ & $\$ 1,184$ & $0.3125 \%$ \\
\hline 2003 & 5 & $0.28 \%$ & $\$ 33$ & $0.0064 \%$ & 37 & $1.21 \%$ & $\$ 874$ & $0.2106 \%$ \\
\hline 2004 & 6 & $0.34 \%$ & $\$ 90$ & $0.0166 \%$ & 19 & $0.62 \%$ & $\$ 953$ & $0.2182 \%$ \\
\hline 2005 & 10 & $0.61 \%$ & $\$ 78$ & $0.0145 \%$ & 13 & $0.43 \%$ & $\$ 836$ & $0.1910 \%$ \\
\hline 2006 & 3 & $0.19 \%$ & $\$ 25$ & $0.0043 \%$ & 16 & $0.53 \%$ & $\$ 1,344$ & $0.2966 \%$ \\
\hline 2007 & 8 & $0.51 \%$ & $\$ 80$ & $0.0132 \%$ & 5 & $0.17 \%$ & $\$ 943$ & $0.2085 \%$ \\
\hline 2008 & 9 & $0.52 \%$ & $\$ 58$ & $0.0090 \%$ & 16 & $0.53 \%$ & $\$ 385$ & $0.0867 \%$ \\
\hline 2009 & 13 & $0.94 \%$ & $\$ 125$ & $0.0240 \%$ & 19 & $0.61 \%$ & $\$ 478$ & $0.1122 \%$ \\
\hline 2010 & 7 & $0.48 \%$ & $\$ 42$ & $0.0073 \%$ & 21 & $0.67 \%$ & $\$ 219$ & $0.0510 \%$ \\
\hline Totals & 463 & & $\$ 6,340$ & & 727 & & $\$ 12,503$ & \\
\hline Average & 20.1 & $0.91 \%$ & $\$ 276$ & $0.0796 \%$ & 31.6 & $0.97 \%$ & $\$ 544$ & $0.1672 \%$ \\
\hline
\end{tabular}

Sources: A. M. Best Co. (2012a and 2012b), National Conference of Insurance Guaranty Funds, National Organization of LifeHealth Guaranty Funds, American Council of Life Insurers, Life Insurance Fact Book (2011).

Note: The failure rate is the number of insolvencies divided by the total number of insurers. Assessments \% of premiums is guaranty fund assessments divided by total insurance premiums for life and property-casualty insurers, respectively.

Life-health assessments are "Called" minus "Refunded. 
Table 3

Insurer Insolvencies: Primary Triggering Events Life Insurers (1969-2011) and Property-Casualty Insurers (1969-2011)

\begin{tabular}{lrr} 
& Life-Health & $\begin{array}{r}\text { Property- } \\
\text { Casualty }\end{array}$ \\
\hline Inadequate pricing/Deficient loss reserves & $29.1 \%$ & $41.9 \%$ \\
Affiliate problems & $18.1 \%$ & $8.3 \%$ \\
Invest problems (overstated assets) & $15.0 \%$ & $7.0 \%$ \\
Rapid growth & $14.1 \%$ & $13.1 \%$ \\
Alleged fraud & $8.8 \%$ & $7.5 \%$ \\
Miscellaneous & $8.1 \%$ & $8.3 \%$ \\
Catastrophe Losses & $\mathrm{NA}$ & $7.1 \%$ \\
Significant business change & $4.5 \%$ & $3.6 \%$ \\
Reinsurance failure & $2.1 \%$ & $3.2 \%$ \\
& & \\
Average number of failures per year & 16.9 & 25.8 \\
\hline Note: Data are only on companies where the cause of impairment was identified. \\
Source: A.M. Best Company (2012c and 2012d).
\end{tabular}


Table 4

Correlations of the Systemic Risk Measure SRISK With Selected Variables

\begin{tabular}{|c|c|c|}
\hline Variable & Correlation & pvalue \\
\hline \multicolumn{3}{|l|}{ Company Characteristics } \\
\hline Ln(Assets) & 0.5988 & $0.0000 * * \star$ \\
\hline Capital/Assets & -0.0331 & 0.5676 \\
\hline Beta & 0.4015 & $0.0000 * * *$ \\
\hline MBS/ Capital & -0.1229 & 0.1263 \\
\hline Total Premiums Ceded/ Capital & 0.0205 & 0.7638 \\
\hline Total Reinsurance Liabilities/ Capital & 0.1839 & $0.0043 * \star \star$ \\
\hline Separate Accounts Assets/ Total Assets & 0.2081 & $0.0007 * \star *$ \\
\hline Total Customer Deposits (Bank)/ Capital & 0.4769 & $0.0000 * * *$ \\
\hline Commercial Paper/ Capital & 0.3477 & $0.0000 * \star *$ \\
\hline Life Insurer Dummy (=1 if Life Insurer) & -0.0327 & 0.5659 \\
\hline \multicolumn{2}{|l|}{ operations in both lines) } & $0.0360 * \star$ \\
\hline \multicolumn{3}{|l|}{ Lines of Business } \\
\hline Workers Compensation Premiums/ Capital & -0.1407 & 0.0522 * \\
\hline Homeowners Multiple Peril Premiums/ Capital & -0.2144 & $0.0029 * \star \star$ \\
\hline Total Other Liability Premiums/ Capital & -0.2477 & $0.0005 * * *$ \\
\hline Private Passenger Automobile Liability Premiums/ Capital & -0.1929 & $0.0075 * * *$ \\
\hline Individual Life Insurance Premiums/ Capital & 0.0125 & 0.8378 \\
\hline Ordinary Individual Annuity Premiums/ Capital & -0.0019 & 0.9751 \\
\hline Group Life Premiums/ Capital & -0.0234 & 0.7018 \\
\hline Group Annuity Premiums/ Capital & 0.1259 & 0.0384 ** \\
\hline Workers Compensation Premiums/ Total Premiums & -0.2867 & $0.0022 * * *$ \\
\hline Homeowners Multiple Peril Premiums/ Total Premiums & -0.2878 & 0.0023 *** \\
\hline Total Other Liability Premiums/ Total Premiums & -0.2848 & 0.0021 *** \\
\hline Private Passenger Automobile Liability Prem./ Total Premiums & -0.3068 & $0.0010 * * *$ \\
\hline Individual Life Insurance Premiums/ Total Premiums & 0.0400 & 0.6758 \\
\hline Ordinary Individual Annuity Premiums/ Total Premiums & 0.5178 & $0.0000 * * *$ \\
\hline Group Life Premiums/ Total Premiums & 0.4189 & $0.0000 * \star \star$ \\
\hline Group Annuity Premiums/ Total Premiums & 0.6675 & $0.0000 * * *$ \\
\hline \multicolumn{3}{|l|}{ Off Balance Sheet Activities } \\
\hline Long Term Debt Due in One Year/ Total Liabilities & 0.3654 & $0.0000 * * *$ \\
\hline Total Fair Value of Derivatives/ Capital & 0.5123 & $0.0000 * * *$ \\
\hline Total Notional Amount of Non-Hedge Derivatives/ Capital & 0.5427 & $0.0000 * * *$ \\
\hline Total Notional Amount of All Derivatives/ Capital & 0.5226 & $0.0000 * * *$ \\
\hline
\end{tabular}

Note: ${ }^{\star \star \star},{ }^{\star \star},{ }^{*}$ signifies significant at the 1,5 , and 10 percent level, respectively. 
Table 5

Summary Statistics for Regression

\begin{tabular}{lrr} 
Variable & Coefficient & std dev \\
\hline SRISK (millions of dollars) & 1.9682 & 3.8830 \\
Ln(Asset) & 11.4138 & 1.7915 \\
Capital/ Assets & 0.8793 & 12.1966 \\
Beta & 1.0769 & 0.5171 \\
MBS/ Capital & 0.5712 & 0.6790 \\
Separate Account Assets/ Assets & 0.1441 & 0.1847 \\
Life Insurance Dummy (=1 if Life Insurer) & 0.9188 & 0.2735 \\
Life and P-C Insurer Business Dummy(=1 if operatior & 0.1188 & 0.3241 \\
Total Other Liability/ Capital & 0.0361 & 0.0637 \\
Group Annuity Premiums/ Capital & 0.0698 & 0.1506 \\
Total Other Liab. Premiums/Total Premiums & 0.0630 & 0.0892 \\
Group Annuity Premiums/Total Premiums & 0.0882 & 0.1360 \\
Total Reinsurance Liabilities/ Capital & 0.0250 & 0.1129 \\
Total Premiums Ceded/ Capital & 0.0890 & 0.1275 \\
\hline
\end{tabular}


Table 6

Robust Ordinary-Least-Squares Regression Results

Dependent Variable: SRISK

\begin{tabular}{|c|c|c|c|c|}
\hline Variable & Coefficient & t-statistic & Coefficien & t-statistic \\
\hline Ln(Asset) & 0.3584 & $2.61 * *$ & 0.3649 & $3.31 * * *$ \\
\hline Capital/ Asset & -1.0322 & -0.68 & 0.2751 & 0.22 \\
\hline Beta & 0.6538 & 1.28 & 0.6643 & 1.30 \\
\hline MBS/ Capital & 0.5990 & 1.79 * & 0.5493 & 2.74 ** \\
\hline Separate Account Assets/ Assets & 2.2916 & 2.29 ** & 2.7700 & $3.12 * \star \star$ \\
\hline Life Insurance Dummy (=1 if Life Insurer) & 1.6844 & $2.40 * *$ & 0.8668 & 0.98 \\
\hline Life and P-C Insurer Dummy (=1 if both lines) & 0.4182 & 1.01 & 0.4008 & 1.01 \\
\hline Total Other Liability/ Capital & -2.0791 & -0.84 & & \\
\hline Group Annuity Premiums/ Capital & 2.4306 & 1.54 & & \\
\hline Total Other Liab. Premiums/Total Premiums & & & -0.3186 & -0.25 \\
\hline Group Annuity Premiums/Total Premiums & & & 5.4150 & $2.70 * \star \star$ \\
\hline Total Reinsurance Liabilities/ Capital & 1.8765 & 4.46 ** & 1.1456 & 2.07 ** \\
\hline Total Premiums Ceded/ Capital & -0.1349 & -0.22 & 0.6390 & 1.14 \\
\hline Constant & -6.0470 & $-2.57 * *$ & -5.9180 & $-2.77 * * *$ \\
\hline F statistic & 43.17 & & & 26.99 \\
\hline Adjusted R-squared & 0.6042 & & & 0.6345 \\
\hline No. of observations & 112 & & & 112 \\
\hline
\end{tabular}

Note: ${ }^{*},{ }^{*}$, and ${ }^{* * *}$ signifies significance at the $1 \%, 5 \%$ and $1 \%$ levels, respectively. 
Figure 1: Failure Rates of U.S. Banks and Insurers

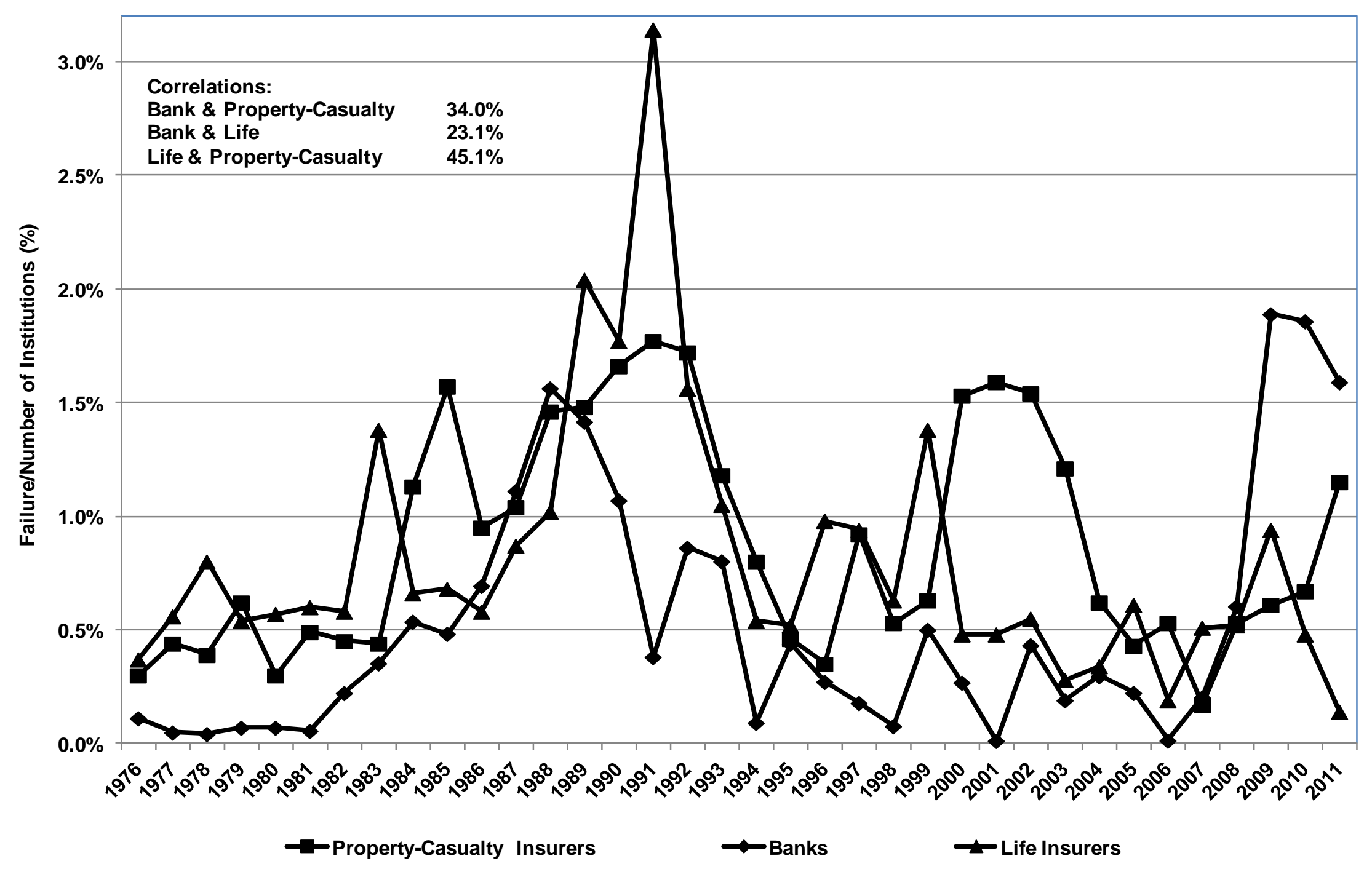

Sources: A.M. Best Company (2012a, 2012b), Federal Deposit Insurance Corporation. 